\title{
Corticotropin-releasing Factor Receptors Are Widely Distributed within the Rat Central Nervous System: An Autoradiographic Study ${ }^{1}$
}

\author{
ERROL B. DE SOUZA,*,2 THOMAS R. INSEL,‡ MARILYN H. PERRIN,§ JEAN RIVIER,§ WYLIE W. VALE,§ \\ AND MICHAEL J. KUHAR*
}

\begin{abstract}
`Departments of Neuroscience, Pharmacology and Experimental Therapeutics, and Psychiatry and the Behavioral Sciences, The Johns Hopkins University School of Medicine, Baltimore, Maryland 21205; $¥$ Laboratory of Clinical Science, National Institute of Mental Health, Bethesda, Maryland 20205; and \$The Clayton Foundation Laboratories for Peptide Biology, The Salk Institute for Biological Studies, San Diego, California 92138
\end{abstract}

\begin{abstract}
Corticotropin-releasing factor (CRF) receptor-binding sites have been localized and quantified in the rat central nervous system (CNS) by autoradiography with an iodine-125-labeled analogue of ovine CRF substituted with norleucine and tyrosine at amino acid residues 21 and 32, respectively. High affinity and pharmacologically specific receptor-binding sites for CRF were found in discrete areas within the rat CNS. CRF receptors were highly concentrated in laminae 1 and 4 throughout the neocortex, the external plexiform layer of the olfactory bulb, the external layer of the median eminence, several cranial nerve nuclei in the brainstem including the facial, oculomotor, trochlear, vestibulocochlear, and trigeminal nuclei, the deep cerebellar nuclei, and the cerebellar cortex. Moderate concentrations of CRF receptors were present in the olfactory tubercle, caudate-putamen, claustrum, nucleus accumbens, nucleus of the diagonal band, basolateral nucleus of the amygdala, paraventricular nucleus of the hypothalamus, mammillary peduncle, inferior and superior olives, medullary reticular formation, inferior colliculus, and brainstem nuclei including tegmental, parabrachial, hypoglossal, pontine, cuneate, and gracilis nuclei, and in spinal cord. Lower densities of CRF binding were found in the bed nucleus of the stria terminalis, central and medial amygdaloid nuclei, and regions of the thalamus, hypothalamus, hippocampus, and brainstem. The distribution of CRF-binding sites generally correlates with the immunocytochemical distribu-
\end{abstract}

Received February 7, 1985; Revised April 23, 1985;

Accepted April 26, 1985

${ }^{1}$ We thank N. Taylor and R. Proctor for technical assistance and S. Wrightson and $M$. Flutka for manuscript preparation. We are especially grateful to Ron Emeson for his help in the iodination and high pressure liquid chromatography purification of corticotropin-releasing factor, to Dr. James Unnerstall for advice and help in preparing iodine-125-labeled standards, and to Dr. Paul Maclean for help in identifying some of the neuroanatomical structures. This study was supported by United States Public Health Service Grants MH25951 and MH00053 and by a grant from the McKnight Foundation. Research at the Peptide Biology Laboratory was supported in part by National Institutes of Health grants AM26741 and HD13527 and was con. ducted in part by the Clayton Foundation for Research, California. M. H. P. and W. W. V. are Clayton Foundation investigators.

${ }^{2}$ To whom correspondence should be sent, at his present address: Neuroscience Branch, Addiction Research Center, National Institute on Drug Abuse, P.O. Box 5180, Baltimore, MD 21224. tion of CRF pathways and with the pharmacological sites of action of CRF. These data strongly support a physiological role for endogenous CRF in regulating and integrating functions in the CNS.

The primary role of a hypothalamic factor in regulating pituitaryadrenocortical secretion has been well established (Harris, 1948; Yasuda et al., 1982). In 1981, Vale and colleagues reported the isolation, characterization, sequence, synthesis, and biologic activity of a 41-amino acid hypothalamic ovine corticotropin-releasing factor (CRF) that fulfills many of the criteria of a physiological regulator of adrenocorticotropin (ACTH) secretion (Spiess et al., 1981; Vale et al., 1981). Synthetic CRF is a potent stimulus for the release of ACTH (Vale et al., 1981, 1983; Turkelson et al., 1981; Gibbs et al., 1982; Grossman et al., 1982; Hook et al., 1982; C. Rivier et al., 1982, 1983; Nussbaum et al., 1983; Orth et al., 1983; Gold et al., 1984), $\beta$-endorphin (Gibbs et al., 1982; C. Rivier et al., 1982; Nussbaum et al., 1983; Vale et al., 1983), and other pro-opiomelanocortin-derived peptides (Al-Noaemi et al., 1982; Meunier et al., 1982; Proulx-Ferland et al., 1982) from the pituitary gland in a variety of species including rats, sheep, monkeys, and humans. In addition to its endocrine activity in the pituitary gland, CRF has a wide variety of extrahypophysiotropic effects. Intracerebroventricular administration of CRF elicits autonomic (Brown et al., 1982a, b; Fisher et al., 1982, 1983; Kalin et al., 1983; Tache et al., 1983; Insel et al., 1984), electrophysiological (Aldenhoff ct al., 1983; Ebcrly ct al., 1983; Ehlors et al., 1983; Valentino et al., 1983), and behavioral (D. R. Britton et al., 1982, 1984; Morley and Levine, 1982; Sutton et al., 1982; Levine et al., 1983; Sahgal et al., 1983; Sirinathsinghij et al., 1983; Koob et al., 1984; Veldhuis and DeWeid, 1984) effects, suggesting that it may play a role in the organism's response to stress. Radioimmunoassay (Fischman and Moldow, 1982; Cote et al., 1983; Hashimoto et al., 1983; Palkovits et al., 1983) and immunocytochemical (Bloom et al., 1982; Bugnon et al., 1982; Olschowka et al., 1982; Cummings et al., 1983; Lerenth et al., 1983; Merchenthaler et al., 1983; Paull and Gibbs, 1983; Swanson et al., 1983) studies have demonstrated that CRF-like immunoreactivity is distributed throughout the rat central nervous system (CNS). These pharmacological and immunohistochemical data suggest that CRF may function as a neurotransmitter or neuromodulator in the CNS.

Earlier we identified and characterized high affinity receptors for CRF in rat (De Souza et al., 1984a) and human (De Souza et al., 1985) anterior pituitary glands and in rat intermediate pituitary (De Souza et al., 1984a). More recently, we reported the autoradiographic identification of CRF receptors in selected regions of rat forebrain 


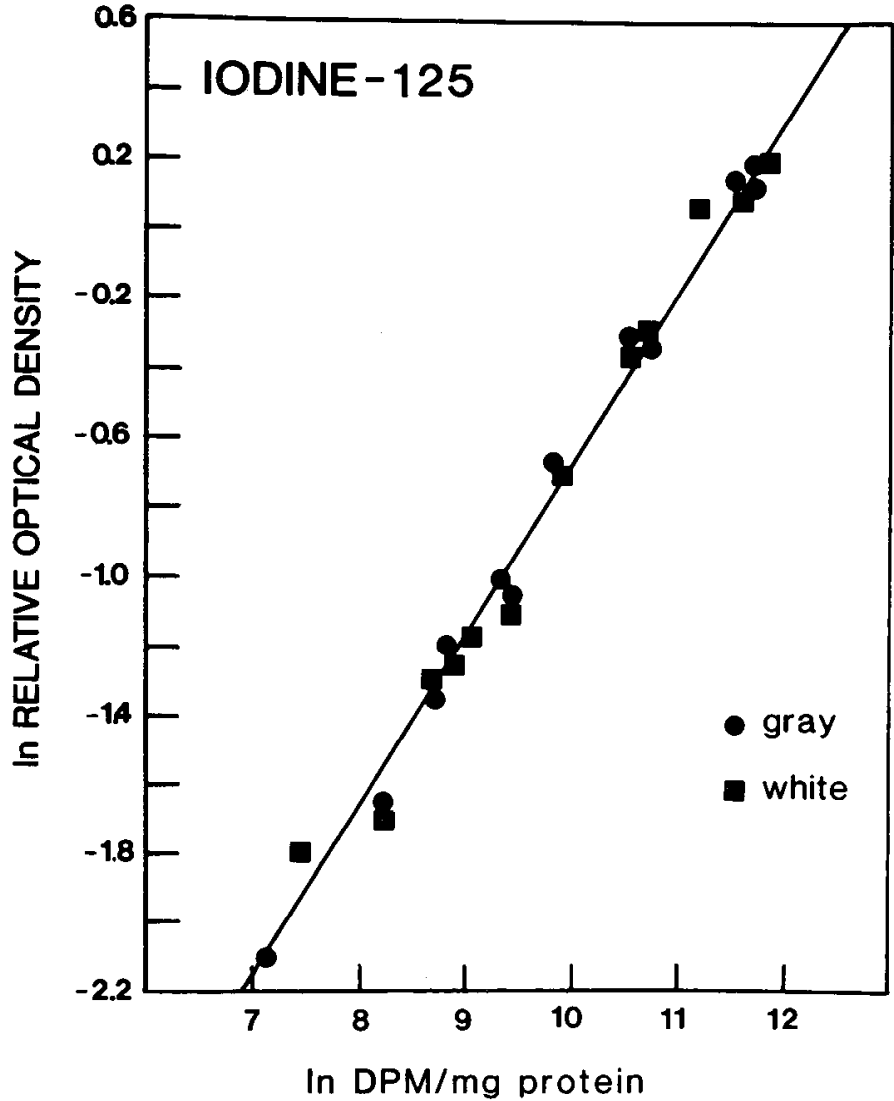

Figure 1. Relationship between the relative optical density in Ultrofilm and the concentration of iodine-125 as derived from the Loats computerized image analysis system for receptor autoradiograms. Tissue blocks of bovine caudate (gray matter) and bovine corpus callosum (white matter) were soaked in iodine-125-labeled compounds, and apposed to Ultrofilm. After exposure, the radioactivity and protein concentration in the standards were measured directly after scraping the tissue sections from the slides. The data are in "relative" optical density because the optical density measurements were not standardized in the image analysis. The regression line had a correlation coefficient of $r \geq 0.99(p<0.001)$. using an iodine-125-labeled ovine CRF analogue substituted with norleucine and tyrosine at amino acid residues 21 and 32, respectively (De Souza et al., 1984b). In this report, we describe in greater detail the autoradiographic distribution of CRF receptors in the rat CNS. These autoradiographic studies have been undertaken to indicate the anatomical loci at which CRF may produce its CNS effects.

\section{Materials and Methods}

lodination and purification of $\mathrm{Nle}^{21}, \mathrm{Tyr}^{32}$-OCRF. $\mathrm{Nle}^{21}, \mathrm{Ty}^{32}$-OCRF was iodinated by reaction of ? $\mu \mathrm{g}$ of peptide with $1.0 \mathrm{mCi}$ of $\mathrm{Na}^{125}$ (Amersham Corp., Arlington Height, IL) in the presence of one lodobead (Pierce Chemical Co., Rockford, IL). The reaction was allowed to proceed for $5 \mathrm{~min}$ at room temperature and was stopped by addition of $5 \mu$ of 2-mercaptoethanol. The iodination mixture was diluted with $3.0 \mathrm{ml}$ of solution A ( $20 \%$ acetonitrile in $0.1 \%$ trifluoroacetic acid) and cycled onto an ODS Sep-Pak cartridge (Waters Associates, Milford, MA) five times; the cartridge was then washed with 20 $\mathrm{ml}$ of solution A and eluted with six $0.5-\mathrm{ml}$ aliquots of solution B $(80 \%$ acetonitrile in $0.1 \%$ trifluoroacetic acid). The two most radioactive fractions were pooled and dried under a stream of $\mathrm{N}_{2}$; the contents were then dissolved in $200 \mu \mathrm{l}$ of solution A. The iodine-125-labeled Nle ${ }^{21}, \mathrm{Tyr}^{32} \cdot \mathrm{OCRF}\left(\mathrm{Nle}^{21},{ }^{125}\right.$ $\mathrm{Ty}^{32}$-oCRF) was purified by reversed phase high pressure liquid chromatography (RP-HPLC) on a Waters $\mathrm{C}_{18}$ (ODS) $\mu$-Bondapak column $(4.6 \mathrm{~mm} \times 30$ $\mathrm{cm}$ ) equilibrated with solution $A$ at a flow rate of $1.0 \mathrm{ml} / \mathrm{min} ; 10 \mathrm{~min}$ after sample injection, a linear gradient to $85 \%$ solution B over 65 min was initiated. Unlabeled $\mathrm{Nle}^{21}$. Tyr ${ }^{32}$-oCRF was detected by absorbance at $220 \mathrm{~nm}$.

Tissue preparation. Male Sprague-Dawley (Madison, WI) rats weighing 200 to $300 \mathrm{gm}$ were anesthetized with pentobarbital and perfused intracardially with 500 to $700 \mathrm{ml}$ of a mixture of equal parts of phosphate-buffered saline and $0.32 \mathrm{M}$ sucrose $(\mathrm{pH} \mathrm{7.4)}$. The brains and spinal cords were then rapidly removed, embedded in homogenized brain paste, and frozen in powdered dry ice. The tissues were sectioned $(8 \mu \mathrm{m})$ using a microtome (Harris; N. Billerica, MA) at $-16^{\circ} \mathrm{C}$, thaw-mounted onto chrome alum/gelatinsubbed microscope slides, and stored at $-20^{\circ} \mathrm{C}$ until used. In biochemical studies involving characterization of the receptor, we used slide-mounted coronal sections of rat forebrain through the diencephalon (one 10- $\mu \mathrm{m}$ section per slide). Sections from at least 15 animals were subsequently used to generate autoradiograms.

Receptor labeling in slide-mounted brain sections. Slide-mounted tissue sections were brought to room temperature and incubated with 0.1 to 0.2 $\mathrm{nM} \mathrm{Nl}{ }^{21},{ }^{125}-\mathrm{Tyr}^{32}$-oCRF in $50 \mathrm{~mm}$ Tris- $\mathrm{HCl}(\mathrm{pH} 7.4)$ containing $5 \mathrm{~mm} \mathrm{MgCl}_{2}$, $2 \mathrm{mM}$ EGTA, $0.1 \%$ bovine serum albumin (BSA), aprotinin $(100 \mathrm{KIJ} / \mathrm{ml})$, and $0.1 \mathrm{~mm}$ bacitracin (Sigma Chemical Co., St. Louis, MO) at room temperature. Blanks were incubated in the same medium with the addition of $1 \mu \mathrm{M} \mathrm{Nl}{ }^{21}$,
Figure 2. RP-HPLC profile of iodine-125 labeled $\mathrm{Nle}^{21}$, $\mathrm{Tyr}^{32}$-oCRF: effects of incubation with brain tissue. Aliquots of $\mathrm{Nle}^{21}$ ${ }^{125}$-Tyr ${ }^{32}$-oCRF in the medium, before $(0)$ and 120 min after $(O)$ incubation with brain tissue were analyzed by RP.HPLC using conditions described under "Materials and Methods." The elution position of unlabeled $\mathrm{Nle}^{21}$. $\mathrm{Tyr}^{32}$-oCRF (dashed line) was determined by absorbance at $220 \mathrm{~nm}$.

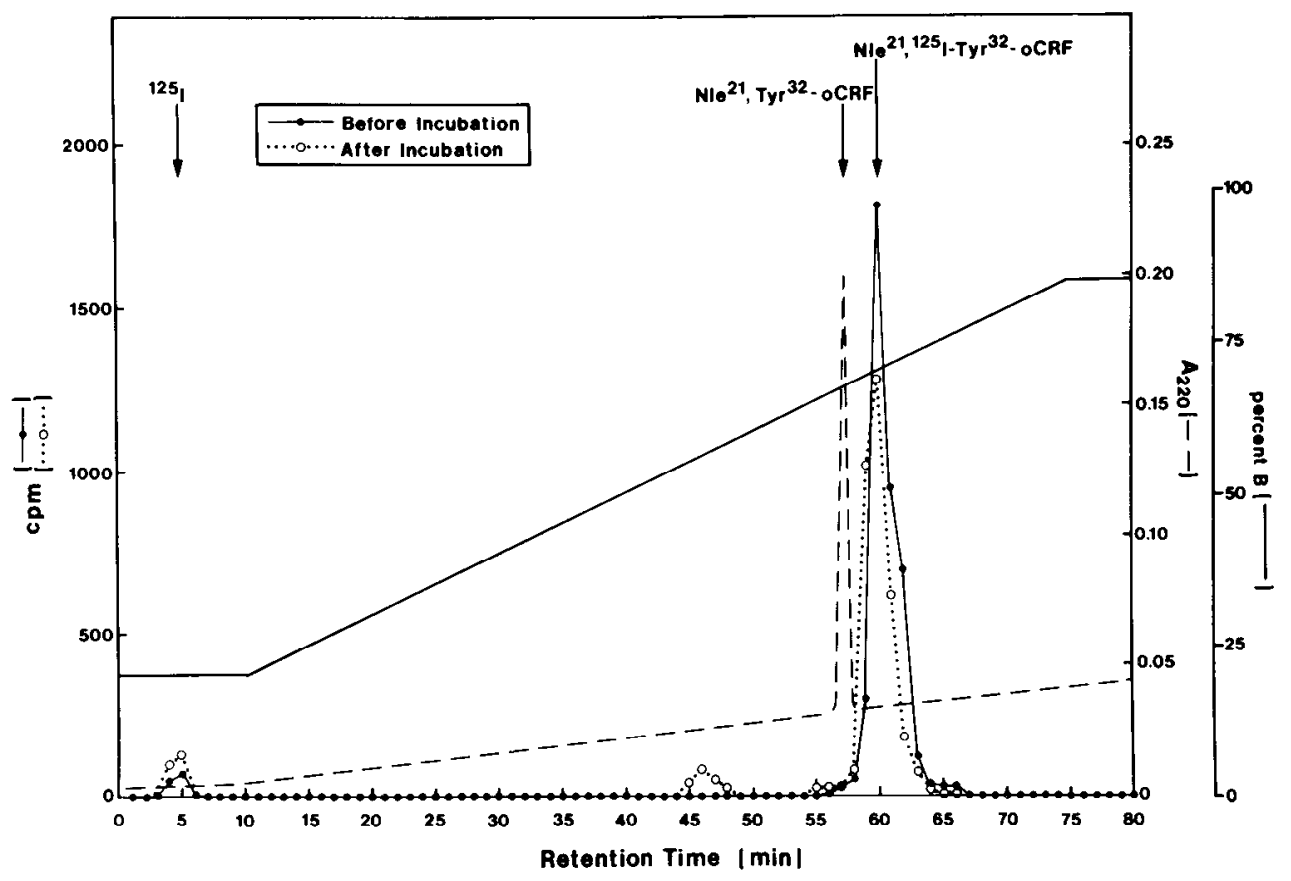


$\mathrm{Tyr}^{32}$-oCRF, oCRF, or rat (human) CRF. Before exposure to $\mathrm{Nle}^{21},{ }^{125}-\mathrm{Ty}^{32}$ oCRF, all tissue sections were incubated at room temperature for two 15min periods in $50 \mathrm{mM}$ Tris- $\mathrm{HCl}(\mathrm{pH} 7.4)$ containing $5 \mathrm{mM} \mathrm{MgCl} \mathrm{M}_{2}$ and. $2 \mathrm{~mm}$ EGTA in order to displace endogenous $\mathrm{CR \Gamma}$ from its receptor. After incubation with $\mathrm{Nl}^{21},{ }^{25}$ - $\mathrm{Tyr}^{32}$-oCRF, tissue sections were washed in Dulbecco's phosphate-buffered saline containing $1 \%$ BSA (fraction V, Sigma), dipped in deionized water, and dried rapidly under a stream of cold, dry air. In preliminary nonautoradiographic studies to determine the time courses of dissociation and association, kinetics, and pharmacology of $\mathrm{Nle}^{21},{ }^{125} \mathrm{i}_{-} \mathrm{yr}^{32}$ oCRF binding to slide-mounted tissues sections, the tissue sections were dried and the tissue was scraped off the glass microscope slide, and the tissue-associated radioactivity was assayed in a gamma counter. In subsequent autoradiographic studies, the tissue sections were incubated with $\mathrm{Nle}^{21},{ }^{25}-\mathrm{Tyr}^{32}$-oCRF for 60 or $90 \mathrm{~min}$ at room temperature and washed for two 5-min periods in Dulbecco's phosphate-buffered saline at $4^{\circ} \mathrm{C}$.

Autoradiography. The dried, labeled, slide-mounted sections were apposed to either ${ }^{3} \mathrm{H}$-Ultrofilm (LKB Instruments, Gaithersburg, MD) (Palacios ct al., 1981) or Kodak NTB.3 cmulsion-coated glass (Young and Kuhar, 1979) or Aclar plastic coverslips, (De Souza et al., 1984b), and after 7 to 14 days of exposure at $4^{\circ} \mathrm{C}$, the autoradiograms were developed and the tissue was stained wilh toluidine blue. Following the staining procedures, the sections were dried, and the coverslips were reapposed and set with Permount.

Data analysis. In autoradiograms prepared with NTB-3 emulsion, grain counts were made by eye using a $\times 100$ oil immersion objective on a Zeiss microscope equipped with a grid-containing eyepiece. In autoradiograms prepared with tritium-sensitive film, optical density readings, construction of standard curves, and rapid quantification were carried out using a Loats PCbased computerized image analysis system (Loats Associates, Westminster, $\mathrm{MD}$ ).

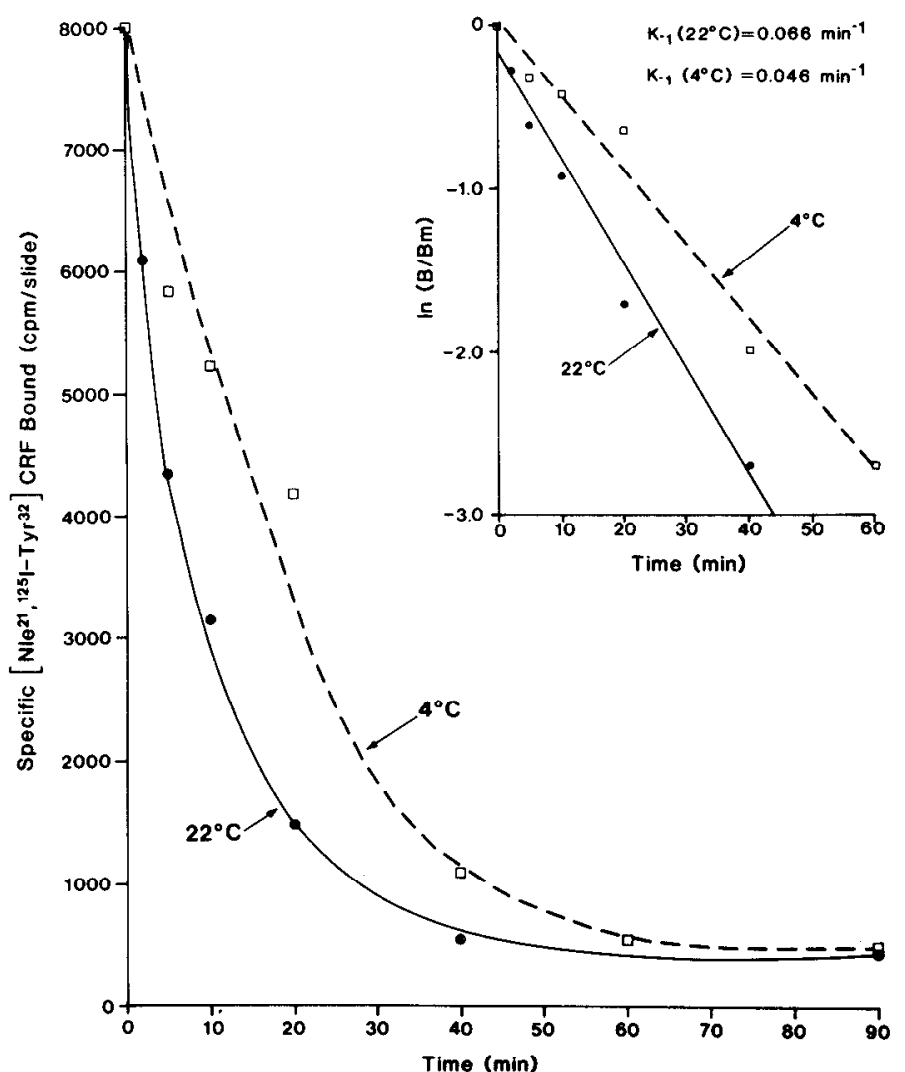

Figure 3. Time course of dissociation of the specific binding of $\mathrm{Nle}^{21},{ }^{125}$ $\mathrm{Tyr}^{32}$-oCRF to slide-mounted tissue sections $(10 \mu \mathrm{m})$ of rat forebrain as a function of temperature. All slide-mounted brain sections were first incubated with $0.2 \mathrm{nM} \mathrm{Nl} \mathrm{e}^{21},{ }^{125} \mathrm{~F}-\mathrm{Ty}^{32}$-oCRF for $60 \mathrm{~min}$ at $22^{\circ} \mathrm{C}$ and then washed in Dulbecco's phosphate-buffered saline containing $1 \%$ BSA at $4^{\circ} \mathrm{C}(\square)$ or at $22^{\circ} \mathrm{C}(\mathbf{)}$. Nonspecific binding was determined in the presence of $1 \mu \mathrm{M}$ oCRF. The inset shows the dissociation rate of specific binding. $B / B m=$ specific binding per maximum specific binding. Each point is the average of three determinations which differed by less than $10 \%$.

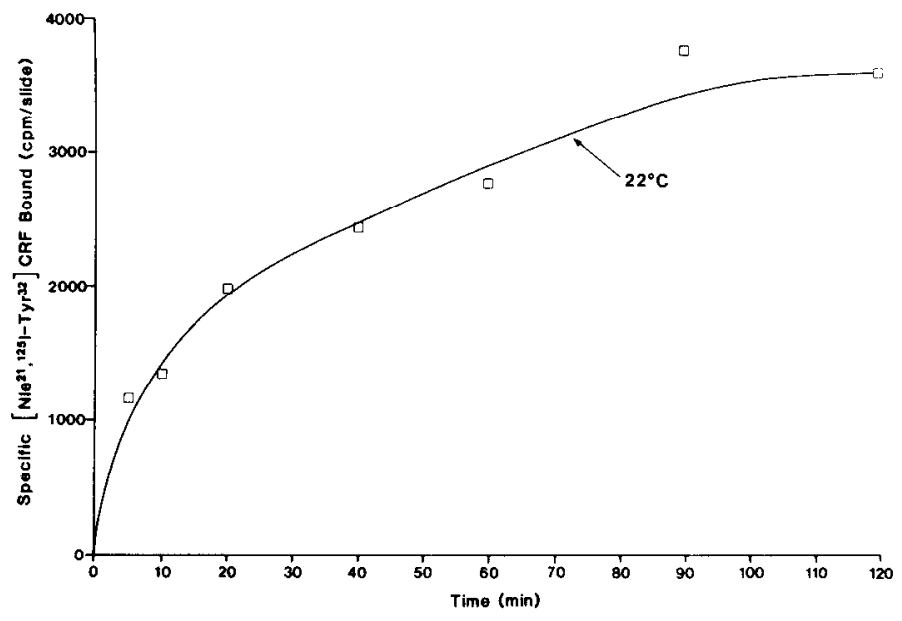

Figure 4. Time course of association of the specific binding of $\mathrm{Nlc}^{21}, 25 \mathrm{f}$ $\mathrm{Tyr}^{32}$-OCRF to slide-mounted sections $(10 \mu \mathrm{m})$ of rat forebrain at $22^{\circ} \mathrm{C}$ Nonspecific binding was determined in the presence of $1 \mu \mathrm{M} \mathrm{OCRF}$. Following the incubation period, all sections were washed for Iwo 5-rinin periods in Dulbecco's phosphate-buffered saline containing $1 \%$ BSA at $4^{\circ} \mathrm{C}$. Each point is the average of four determinations which differed by less than $10 \%$.

Slide-mounted tissue sections $(8 \mu \mathrm{m})$ of bovine caudate (gray matter) and bovine corpus callosum (white matter) were soaked for 10 min in increasing concentrations $\left(10^{3}\right.$ to $10^{6} \mathrm{cpm} / 100 \mu$ lof water) of iodine-125-labeled histamine at room temperature and dried rapidly under a stream of cold, dry air. The iodine-125-labeled gray and white matter standards were apposed to ${ }^{3} \mathrm{H}$-Ultrofilm along with the CRF-labeled brain sections. After exposure, the tissue sections were scraped from the slides, and the radioactivity and protein concentration in the gray and white matter standards were measured directly. The relationship between relative optical density in Uitrofilm and the concentration of iodine-125 in the gray and white matter standards is shown in Figure 1. We utilized a power function to describe the relationship between optical density and radioactivity since the Loats image analysis system indicated a best fit for the power function as opposed to a linear or log function. The regression line had a correlation coefficient of $r \geq 0.99(\rho<$ 0.001 ). No difference was found in the autoradiographic efficiency in gray and white matter labeled with iodine-125. By generating such a standard curve concomitantly with the $\mathrm{Nle}^{21}{ }^{125}$ - $-\mathrm{Tyr}^{32}$-OCRF autoradiograms, the film optical density readings of the samples were related to the molar concentration of radioactivity.

\section{Results}

RP-HPLC analysis of iodine-125-labeled N/e ${ }^{21}, \mathrm{Tyr}^{32}$-oCRF. The RP-HPLC profile of iodine-125-labeled and unlabeled $\mathrm{Nle}^{21}$, $\mathrm{Tyr}^{32}$ oCRF is shown in Figure 2. Unlabeled $\mathrm{Nle}^{21}, \mathrm{Tyr}^{32}$-oCRF eluted at $57.5 \mathrm{~min}$ and the iodine-125-labeled peptide eluted at $60 \mathrm{~min}$.

To determine whether the incubation conditions used in labcling CRF receptors on slide-mounted tissue sections resulted in any appreciable degradation of the ligand, we ran analytical profiles of aliquots of the medium before and $120 \mathrm{~min}$ after incubation with tissue. As seen in Figure 2, 120 min after incubation, approximately $92 \%$ of $\mathrm{Nle}^{21},{ }^{125} \mathrm{-Tyr}{ }^{32}$-oCRF remained undegraded. The major degradation product ( $6.5 \%$ of total radioactivity) eluted at 45 to 48 min. In addition, minor peaks representing 3\% (before incubation) and $4.5 \%$ (after incubation) of the total radioactivity eluted in the same position as iodine-125. These data demonstrate the stability of the incubation conditions for labeling CRF receptors in slidemounted tissue sections.

Biochemical characterization of CRF receptors in slide-mounted tissue sections. We carried out a series of kinetic and pharmacologic studies to define the incubation parameters and assess the properties of CRF receptors in slide-mounted brain sections. First, the rate of dissociation of $\mathrm{Nle}^{21},{ }^{125} \mathrm{l}-\mathrm{Tyr}^{32}$-oCRF binding was determined as a function of temperature (Fig. 3). Slide-mounted sections of rat brain through the diencephalon were first incubated with $0.2 \mathrm{~nm}$ $\mathrm{Nle}^{21},{ }^{125} / \mathrm{-Tyr^{32 }}$-oCRF for $60 \mathrm{~min}$ at $22^{\circ} \mathrm{C}$ and then washed for various 

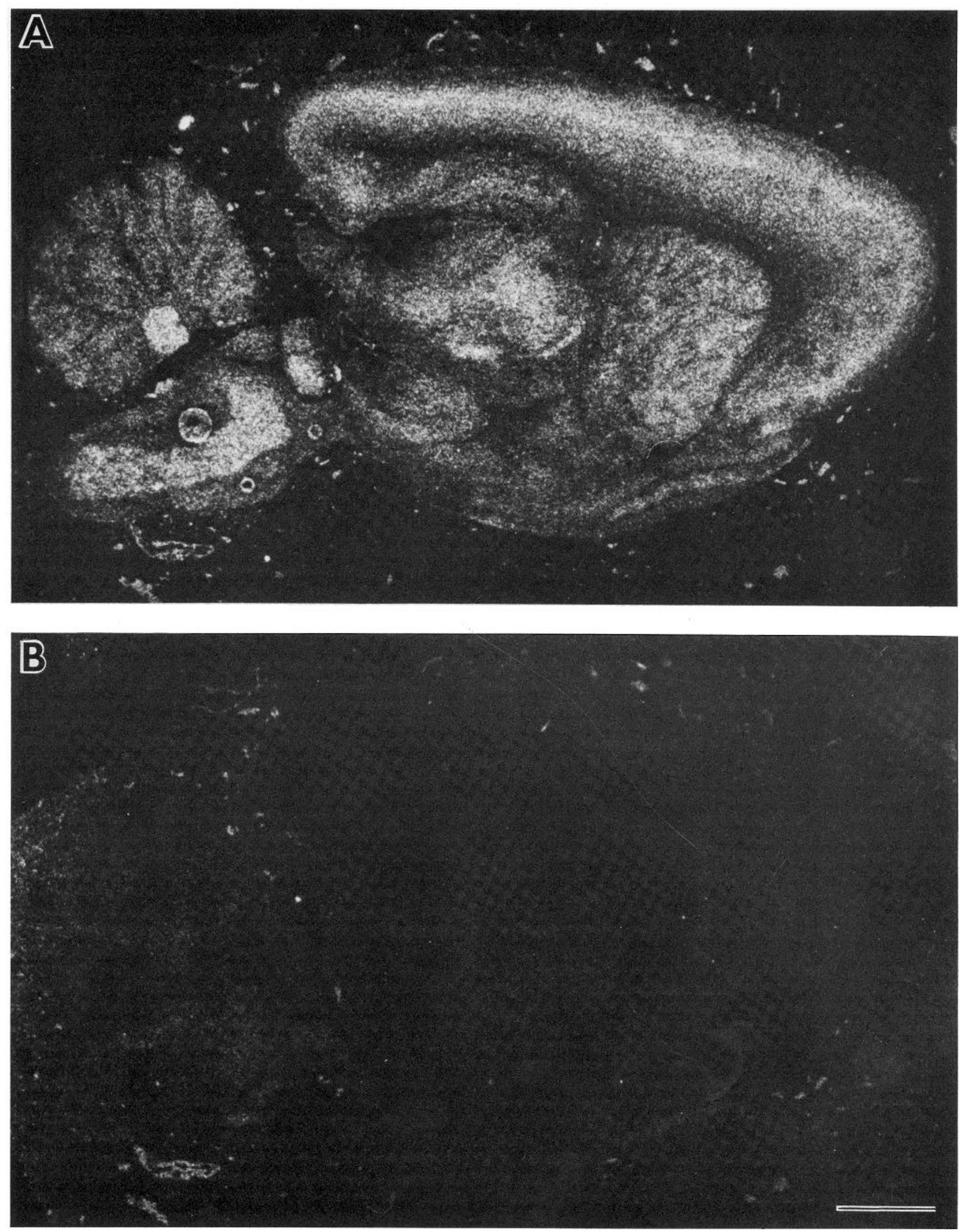

Figure 5. Autoradiographic distribution of CRF receptor-binding sites in rat brain, labeled with $\mathrm{Nle}^{21}$, ${ }^{125}$-Tyr ${ }^{32}$-oCRF. $A$ and $B$ are darkfield photomicrographs $\left({ }^{3} \mathrm{H}\right.$-Ultrofilm), showing the distribution of autoradiographic grains in saggital sections of rat brain. In darkfield illumination the autoradiographic grains, i.e., binding sites, appear as white spots and the tissue is not visible. Thus, the brightest areas have the highest concentration of binding sites. $A$ shows the "total" binding and $B$ shows the absence of specific receptor binding when $1 \mu \mathrm{M}$ unlabeled Nle ${ }^{21}$. Tyr $\mathrm{r}^{32}$-oCRF is included in the incubation buffer (blank). Bar $=2 \mathrm{~mm}$. 


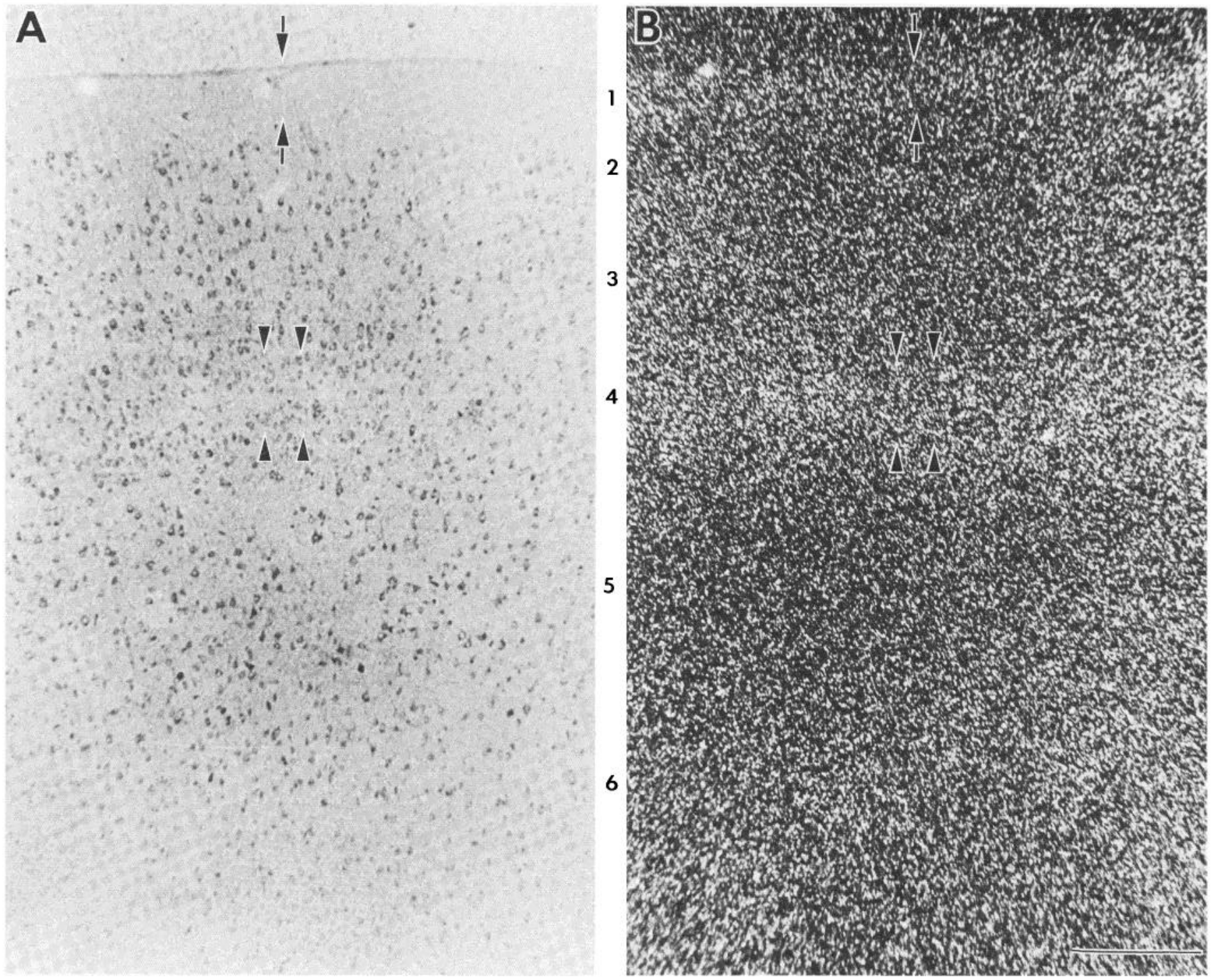

Figure 6. Autoradiographic localization of CRF receptors in the cerebral cortex (parietal region). A, Brightfield photomicrograph of a toluidine blue-stained section (coronal plane) showing the six layers ( 1 to 6 ) of the neocortex. $B$, Darkfield photomicrograph showing the autoradiographic grain distribution on emulsion-coated coverslips over the same area shown in A. In B note the high concentration of grains in lamina 1 (between arrows) and lamina 4 (between arrowheads) of the neocortex. Bar $=25 \mu \mathrm{m}$.
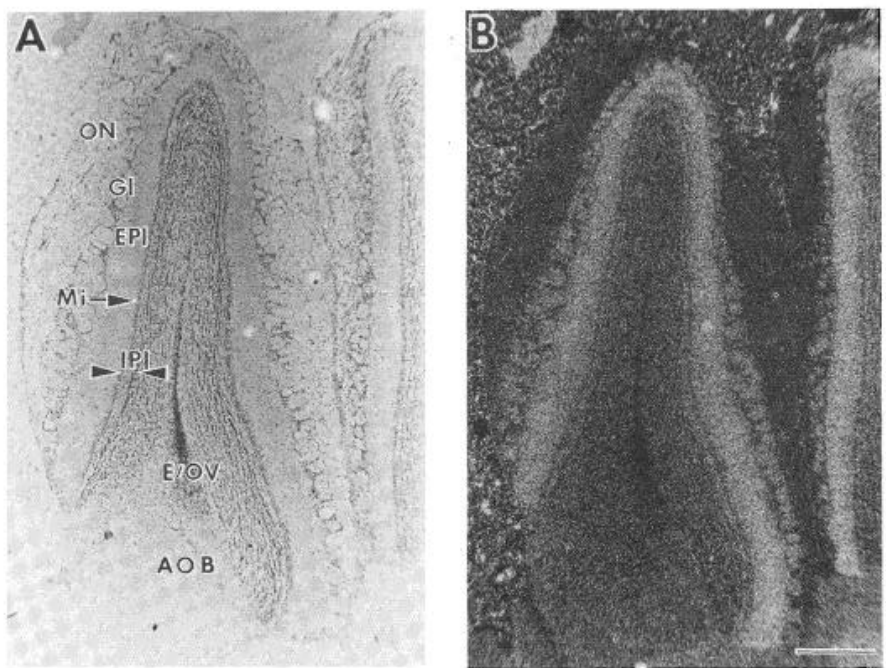

Figure 7. Autoradiographic localization of CRF receptors in rat olfactory bulb. A, Brightfield photomicrograph of a toluidine blue-stained tissue show- times in Dulbecco's phosphate-buffered saline containing 1\% BSA at either $4^{\circ} \mathrm{C}$ or at $22^{\circ} \mathrm{C}$. Nonspecific binding was determined in the presence of $1 \mu \mathrm{M}$ OCRF. The dissociation rates $\left(K_{-1}\right)$ at $4^{\circ} \mathrm{C}$ and at $22^{\circ} \mathrm{C}$ were 0.046 and $0.066 \mathrm{~min}^{-1}$, respectively.

Next, we examined the time course of association of $\mathrm{Nle}^{21},{ }^{125} \mathrm{~F}$ $\mathrm{Tyr}^{32}$-oCRF with receptors at $22^{\circ} \mathrm{C}$ in slide-mounted sections of rat forebrain (Fig. 4). Slide-mounted tissue sections were incubated with $0.2 \mathrm{~nm} \mathrm{Nle}^{21},{ }^{125}-\mathrm{Tyr}^{32}$-oCRF for various times at $22^{\circ} \mathrm{C}$, rinsed for two 5 -min periods at $4^{\circ} \mathrm{C}$, and assayed for radioactivity. The specific binding increased with time during the first 60 min of incubation, after which there was no further significant increase. Based on these

ing the histology of the olfactory bulb sectioned in the horizontal plane. $B$, Darkfield photomicrograph showing the autoradiographic grain distribution on emulsion-coated coverslips over the same area shown in $A$. In darkfield illumination the autoradiographic silver grains appear as white spots and the tissue is not visible. In $B$, note the high concentration of grains in the external plexiform layer and glomerular layer with a somewhat lower concentration in the internal plexiform layer (arrowheads in $A$ ). Bar $=200 \mu \mathrm{m}$. $A O B$, accessory olfactory bulb; $E / O V$, ependymal olfactory ventricle; $E P I$, external plexiform layer; GI, glomerular layer; IPI, internal plexiform layer; $M i$, mitral cell layer; $\mathrm{ON}$, olfactory nerve layer. 

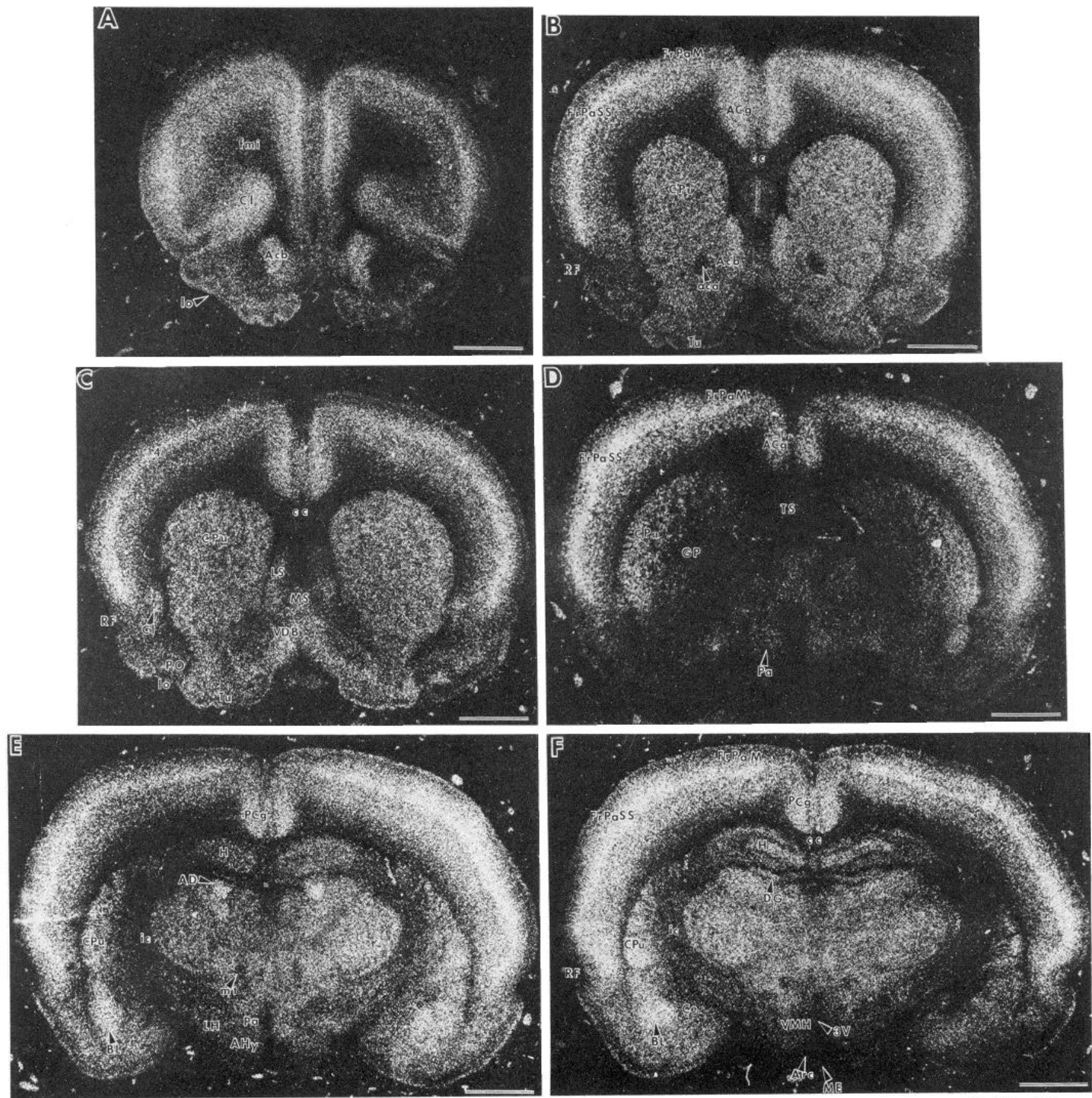

Figure $8{ }^{3}$ Autoradiographic mapping of the distribution of CRF receptor-binding sites in coronal sections of rat brain, labeled with $\mathrm{Nle}^{21}$, ${ }^{125}$-Tyr ${ }^{32}$-oCRF. $A$ to $L$ are darkfield photomicrographs (tritium-sensitive Ultrofilm) showing the distribution of autoradiographic grains in coronal sections of rat forebrain ( $A$ to $F)$ and brainstem $(G$ to $L$ ). The autoradiograms pictured here are from one animal and are organized rostrocaudally. The anatomy of the CRF binding sites was confirmed in sections where autoradiograms were generated by apposition of emulsion-coated coverslips that were permanently affixed to the slides. A concentration of $0.2 \mathrm{nM} \mathrm{Nle}^{21},{ }^{125}$ - $\mathrm{Tyr}^{32}$-oCRF was used to label these sections. Nonspecific binding, determined in the presence of $1 \mu \mathrm{M}$ unlabeled $\mathrm{Nle}^{21}$, ${ }^{125}$ - Tyr $^{32}$-oCRF was uniform and comparable to that shown in Figure $5 B$. See the text for details. Bar $=2 \mathrm{~mm}$.

${ }^{3}$ The abbreviations used in Figure 8 are: 3 , principal oculomotor nucleus; $3 \mathrm{~V}$, third ventricle; 7 , facial nucleus; $7 n$, facial nerve or root of facial nerve; 12, hypoglossal nucleus; aca, anterior commissure, anterior part; $A c b$, accumbens nucleus; $A C g$, anterior cingulate cortex; $A D$, anterodorsal thalamic nucleus; $A H y$, anterior hypothalamic area; $A q$, cerebral aqueduct (Sylvius); Arc, arcuate hypothalamic nucleus; BL, basolateral amygdaloid nucleus; $C b$, cerebellum; $c c$, corpus callosum; $C e$, central amygdaloid nucleus; $\mathrm{CG}$, central gray; $\mathrm{Cl}$, claustrum; $\mathrm{Co}$, cochlear nucleus; $\mathrm{CPu}$, caudateputamen; $\mathrm{Cu}$, cuneate nucleus; $D G$, dentate gyrus; $D p M e$, deep mesencephalic nucleus; $D R$, dorsal raphe nucleus; DTg, dorsal tegmental nucleus (Gudden); Ent, entorhinal cortex; Fl, flocculus; fmi, forceps minor of the corpus callosum; FrPaM, frontoparietal cortex, motor area; FrPaSS, frontoparietal cortex, somatosensory area; GP, globus pallidus; Gr, gracile nucleus; $H$, hippocampus; IC, inferior colliculus; ic, internal capsule; Int, interpositus cerebellar nucleus; $I O$, inferior olive; $I P$, interpeduncular nucleus; $L a t C$, lateral cervical nucleus; $L C$, locus ceruleus; $L H$, lateral hypothalamic area; II, lateral lemniscus; $l o$, lateral olfactory tract; $L S$, lateral septal nucleus; $M d$, reticular nucleus of the medulla; $M E$, median eminence; $M S$, medial septal nucleus; $M T$, medial terminal nucleus of the accessory optic tract; $P a$, paraventricular hypothalamic nucleus; $P C g$, posterior cingulate cortex; $P F I$, paraflocculus; $P n$, pontine nuclei; $P n O$, pontine reticular nucleus, oral part; $P O$, primary olfactory (piriform) cortex; Pr5, principal sensory trigeminal nucleus; $p y$, pyramidal tract; $R F$, rhinal fissure; $R P n$, raphe pontis nucleus; $R S p l$, retrosplenial cortex; $S$, subiculum; $s 5$, sensory root of the trigeminal nerve; sol, solitary tract; $s p 5$, spinal tract of the trigeminal nerve; Sp5C, nucleus of the spinal tract of the trigeminal nerve, caudal part; Str18a, striate cortex, area $18 \mathrm{a} ; \mathrm{TS}$, triangular septal nucleus (interstitial nucleus of the ventral hippocam. pal commissure); $T u$, olfactory tubercle; $V D B$, nucleus of the vertical limb of the diagonal band, dorsal part; Ve, vestibular nucleus; $\mathrm{VMH}$, ventromedial hypothalamic nucleus. 

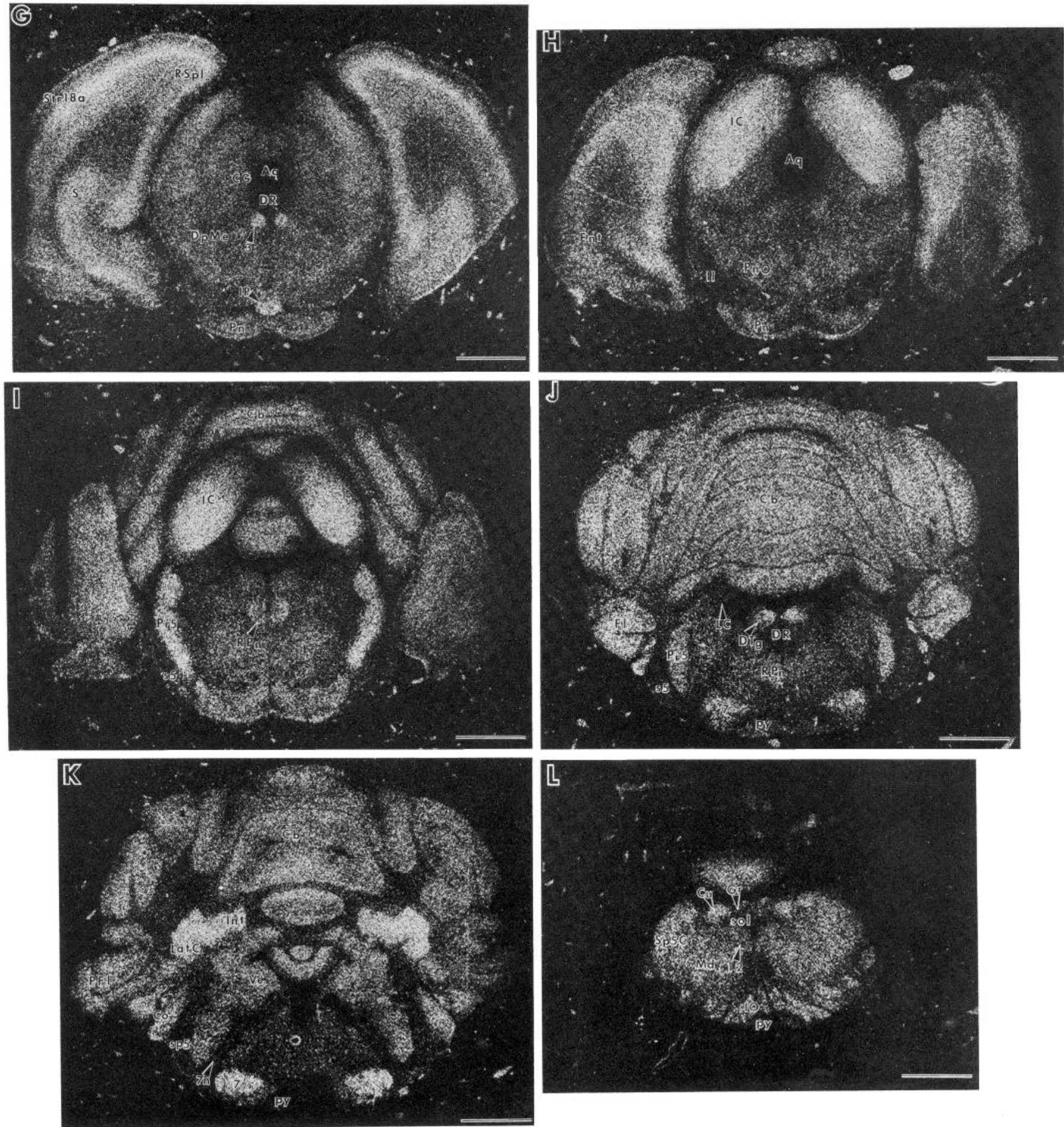

Figure $8, G-L$

observations, all subsequent autoradiographic studies utilized a 60 to 90 -min incubation at $22^{\circ} \mathrm{C}$ followed by two 5 -min washes at $4^{\circ} \mathrm{C}$. In a previous study (De Souza et al., 1984b), we defined the characteristics of $\mathrm{Nle}^{21},{ }^{125} \mathrm{-}-\mathrm{Tyr}^{32}$-oCRF binding in rat brain under conditions defined above. We incubated serial slide-mounted tissue sections with increasing concentrations of CRF-related and unrelated peptides. The binding of $\mathrm{Nle}^{21},{ }^{125} / \mathrm{Tyr}^{32}-\mathrm{OCRF}$ in rat striatum was saturable and, on Scatchard analysis, revealed a high affinity component with an apparent $K_{\mathrm{d}}$ of $6.2 \pm 0.8 \mathrm{~nm}$ and a low affinity binding site with a $K_{\mathrm{d}}$ of approximately $100 \mathrm{nM}$. In competition studies, $1 \mu \mathrm{M}$ rat (human) CRF and ovine CRF inhibited $105 \%$ and $81 \%$, respectively, of the specific $\mathrm{Nle}^{21},{ }^{125} \mathrm{I}-\mathrm{Tyr}^{32}$-oCRF binding in rat striatum. Two fragments of oCRF, CRF(1-39) and CRF(1-22), which are weak in stimulating pro-opiomelanocortin-derived peptide secretion from the pituitary gland, displaced about $30 \%$, and the unrelated peptide arginine vasopressin did not inhibit the binding.

Autoradiographic studies. The autoradiographic distribution of CRF-binding sites is shown in Figures 5 to 10 and quantified in Tables I to III. In general, nearly all of the $\mathrm{Nle}^{21},{ }^{125} \mid \mathrm{Ty}^{32}$-oCRF binding was to gray matter areas with nonsignificant levels present in white 

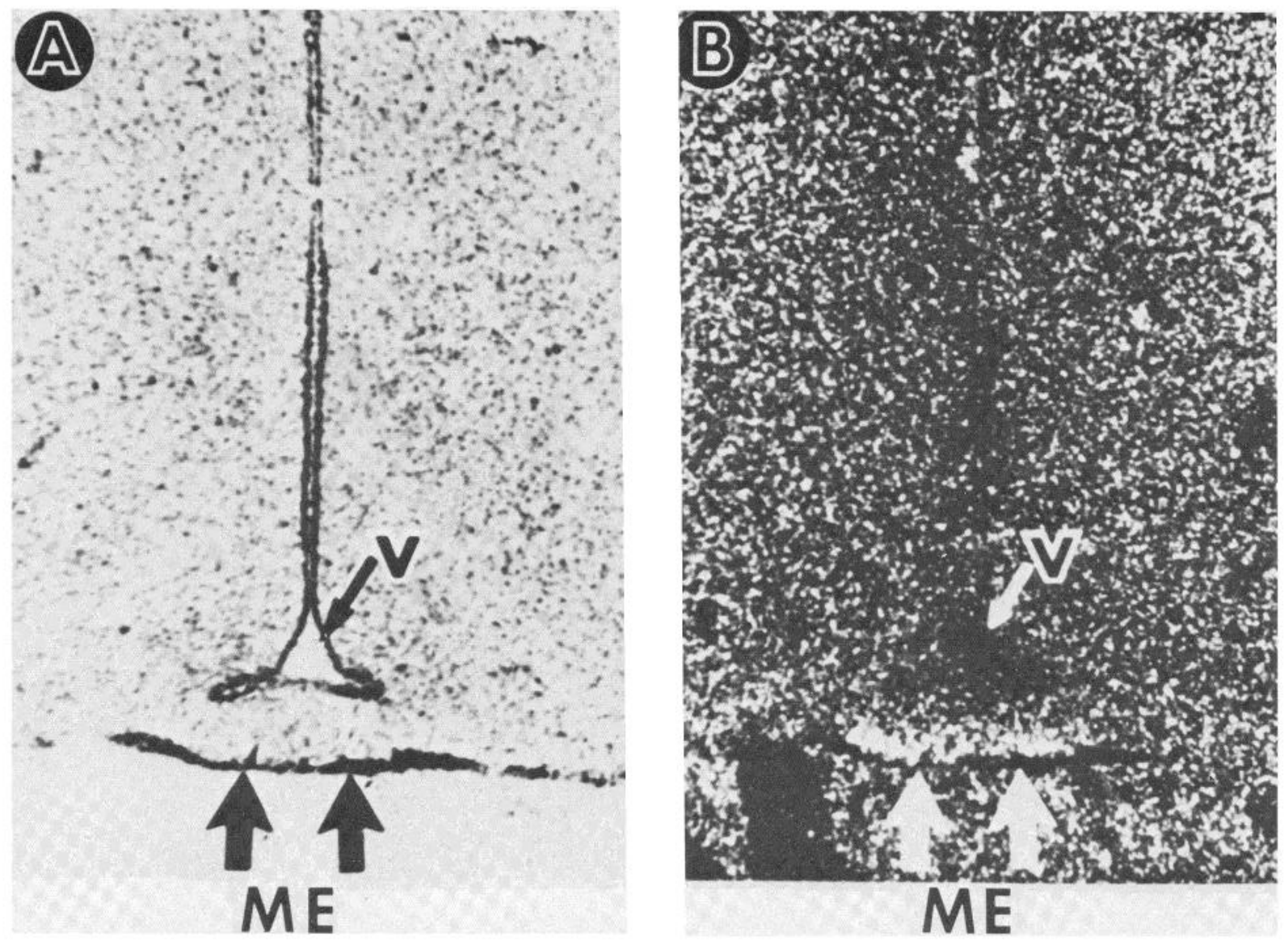

Figure 9. Binding of $\mathrm{Nle}^{21},{ }^{125} \mathrm{-Tyr} \mathrm{T}^{32}$-oCRF in the rat medial hypothalamus. A, Brightfield photomicrograph of a toluidine blue-stained tissue section showing a high power view of the median eminence of the hypothalamus $(M E)$ at the base of the third ventricle $(V)$. B, Darkfield photomicrograph showing the autoradiographic grain distribution on Kodak NTB-3 emulsion-coated coverslips over the same area shown in $A$. In $B$ note that the concentration of grains in the external layer of the median eminence (arrows) is higher than in the remainder of the hypothalamus.

matter tracts such as corpus callosum, fornix, and optic chiasm. In describing the distribution of $\mathrm{Nle}^{21},{ }^{125}-\mathrm{Tyr}^{32}$-oCRF-binding sites which follows, qualitative expressions of receptor density will correspond to the relative binding values in Table III: very low levels, specific binding of 0 to $20 \mathrm{fmol} / \mathrm{mg}$ of protein; low levels, 20 to 40 $\mathrm{fmol} / \mathrm{mg}$ of protein; moderate levels, 40 to $80 \mathrm{fmol} / \mathrm{mg}$ of protein; high levels, 80 to $100 \mathrm{fmol} / \mathrm{mg}$ of protein; and very high levels, $>100$ $\mathrm{fmol} / \mathrm{mg}$ of protein. Nonspecific binding was consistently uniform in all brain areas (Fig. $5 B$ ) and was subtracted from the total binding to calculate specific binding.

CRF receptors were found throughout the neocortex. Within the neocortex, high grain densities were present in laminae 1 and 4 with moderate levels observed in lamina 2, 3, 5 and 6 (Fig. 6, Table II). Although this laminar distribution of $\mathrm{Nle}^{21},{ }^{125} \mathrm{~F}-\mathrm{Tyr}^{32}$-OCRF-binding sites was maintained throughout the neocortex, on the average, more binding sites were found in somatosensory (see Fig. $8, B$ to $F$ ), striate (see Fig. $8 H$ ), and entorhinal (see Fig. $8 \mathrm{G}$ ) cortex than in motor (see Fig. $8, B$ to $F$ ) and cingulate (see Fig. $8, B$ to $F$ ) cortex.

A change in the pattern of CRF binding was seen at the transition of the neocortex and the pyriform cortex near the rhinal fissure (see Fig. 8, $B$ and $C$ ). In the pyriform cortex, a high density of binding sites was present only in lamina I, with much lower levels found in the remaining laminae. A high grain density was found in the external plexiform layer of the olfactory tubercle, whereas low density binding was observed in the pyramidal and polymorphic layers of the tubercle as well as in the islands of Calleja (see Fig. $8 \mathrm{C}$ ). No specific CRF binding was present in the lateral olfactory tract (see Fig. 8, A to $\mathrm{C}$ ). In the olfactory bulb (Fig. 7, Table I), Nle ${ }^{21},{ }^{125} \mathrm{-Tyr^{32 }}-\mathrm{oCRF}$ binding sites were highly localized to the external plexiform layer and the adjacent glomerular layer. Low to negligible concentrations of receptors were found in the remainder of the bulb including the nerve fiber, internal plexiform, mitral cell body, and internal granule layers of the olfactory bulb.

In the corpus striatum, moderate levels of CRF receptors were observed in the caudate-putamen (Fig. $8, B$ to $F$ ). The adjacent globus pallidus (Fig. 8D) had a low density of CRF-binding sites. Moderate grain densities were observed over the claustrum (Fig. 8, $A$ and $C)$.

Moderately high levels of specific binding were associated with the nucleus accumbens (Fig. $8 A$ ), with slightly higher grain densities observed over the medial than the lateral parts of this nucleus (Fig. $8 B$ ). Low to moderate grain densities were observed over both the vertical and horizontal limbs of the nucleus and tract of the diagonal band (Fig. $8 \mathrm{C}$ ). Low levels of CRF binding were present in the areas of medial and lateral septal nuclei (Fig. $8 \mathrm{C}$ ) and triangular septal nucleus (Fig. 8D), and slightly higher levels were present in the bed nucleus of the stria terminalis. In the amygdala, low concentrations of receptors were observed in the medial and central nuclei, whereas a moderate concentration of CRF receptors was present in the basolateral nucleus (Fig. 8, $E$ and $F$ ).

There was a fairly uniform, low to moderate level of CRF-binding sites throughout the thalamus with a slightly higher concentration of grains observed in the lateral compared to the medial thalamus (Fig. $8, E$ and $F$ ). In the dorsal thalamic complex, a higher concentration of receptors was associated with the anterodorsal nucleus (Fig. $8 E$ ). The habenular nuclei of the epithalamus contained a moderate level of CRF-binding sites.

In general, the hypothalamus contained a low density of autora- 

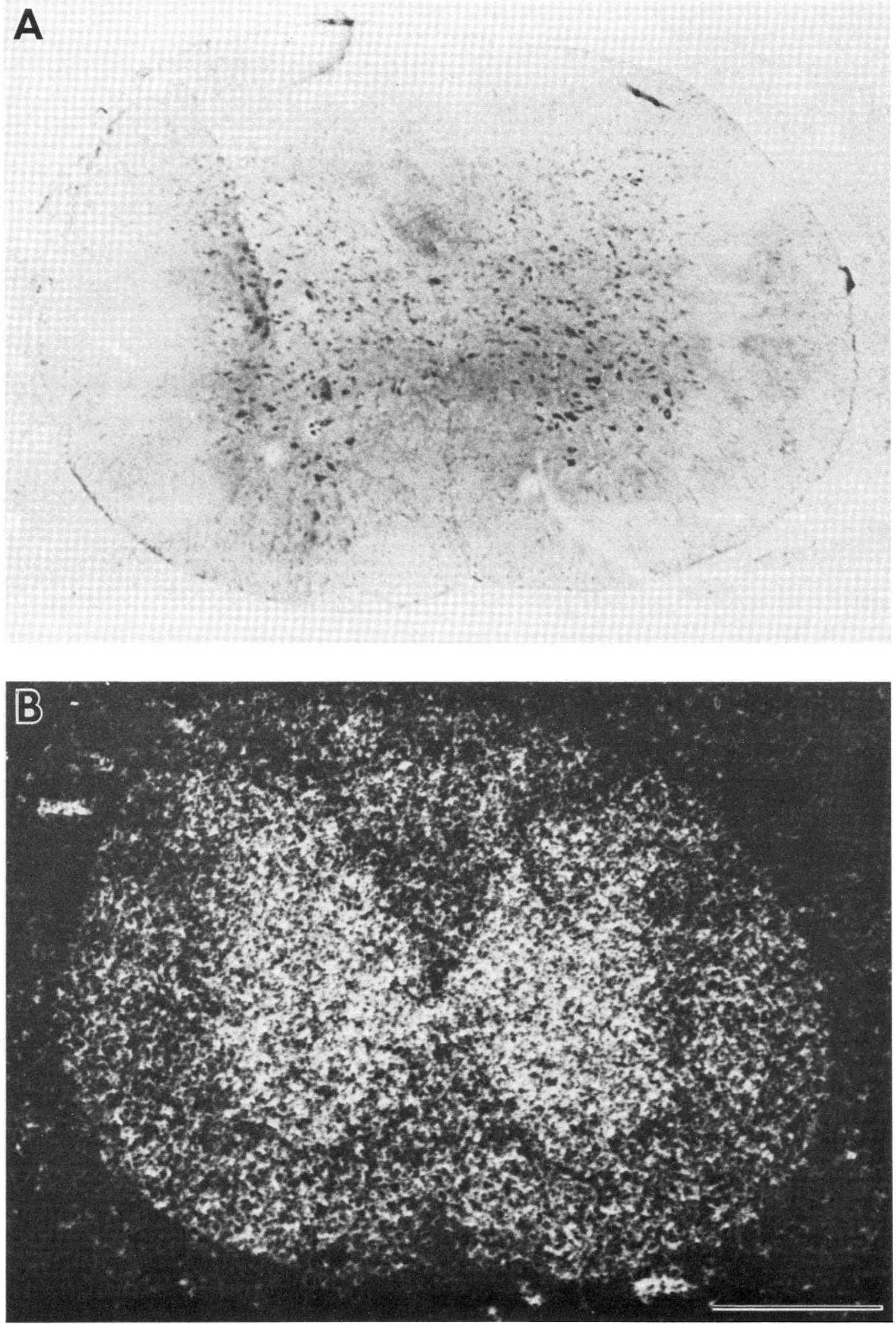

Figure 10. Distribution of CRF receptors in rat spinal cord. A, Brightfield photomicrograph of a toluidine blue-stained section of the cervical spinal cord. $B$, Darkfield photomicrograph showing the autoradiographic grain distribution on tritium-sensitive Ultrofilm over the same area shown in $A$. In $B$, note the lower concentration of grains in Rexed layers 1 to 3 of the dorsal horn than in the rest of the dorsal horn or the entire ventral horn. Bar $=500 \mu \mathrm{m}$. 


\section{TABLE I}

Distribution of CRF-binding sites in the rat olfactory bulb

Data represent the total density of autoradiographic silver grains per 500 $\mu \mathrm{m}^{2}$ as visualized over a given locus and are repurled as mean \pm SEM Nonspecific binding as defined by the density of grains in the presence of 1 $\mu \mathrm{M} \mathrm{Nl}{ }^{21}, \mathrm{Tyr}^{32}$-oCRF was $81.9 \pm 2.4$ grains $/ 500 \mu \mathrm{m}^{2}$ and was uniform over the entire bulb. These data are semiquantitative since the relationship between grain density and tissue radioactivity is not linear (Kuhar and Unnerstall, 1985). Therefore, the nonspecific binding was not subtracted from the above values. The mean grain counts were determined in six $475-\mu \mathrm{m}^{2}$ areas from three horizontal sections through the olfactory bulb.

\begin{tabular}{|c|c|}
\hline Area & $\begin{array}{c}\text { Total } \mathrm{Nie}^{21},{ }^{125}-\mathrm{Ty}^{32} \mathrm{OCRF}- \\
\text { binding Sites } \\
\text { (grains/500 } \mu \mathrm{m}^{2} \text { ) }\end{array}$ \\
\hline Nerve fiber layer & $82.0 \pm 3.4$ \\
\hline Glomerular layer & $172.1 \pm 4.2$ \\
\hline External plexiform layer & $187.4 \pm 6.3$ \\
\hline Mitral cell body layer & $116.7 \pm 4.8$ \\
\hline Internal plexiform layer & $148.4 \pm 4.8$ \\
\hline Internal granule cell layer & $100.7 \pm 4.7$ \\
\hline Ependyma/olfactory ventricle & $81.2 \pm 2.3$ \\
\hline Accessory olfactory bulb & $91.0 \pm 2.9$ \\
\hline
\end{tabular}

TABLE \|

Laminar distribution of CRF-binding sites in the cerebral cortex

Data represent the total density of autoradiographic silver grains per 500 $\mu \mathrm{m}^{2}$; values are mean $\pm \mathrm{SEM}$. Nonspecific binding as defined by the density

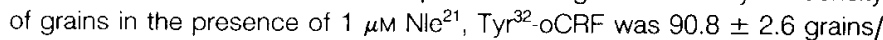
$500 \mu \mathrm{m}^{2}$ and was uniform over the entire cortex. These data are semiquantitative since the relationship between grain density and tissue radioactivity is not linear (Kuhar and Unnerstall, 1985). Therefore, the nonspecific binding was not subtracted from the above values. The mean grain counts were determined in six $475-\mu \mathrm{m}^{2}$ areas from three horizontal sections through the parietal cortex

\begin{tabular}{cc}
\hline Lamina & $\begin{array}{c}\text { Total } \mathrm{Nle}^{21},{ }^{125}-\mathrm{Tyr}^{32} \text {-oCRF- } \\
\text { binding Sites } \\
\text { (grains/500 } \mu \mathrm{m}^{2} \text { ) }\end{array}$ \\
\hline 1 & $164.4 \pm 5.6$ \\
2 & $122.9 \pm 6.6$ \\
3 & $136.2 \pm 4.8$ \\
4 & $208.2 \pm 5.9$ \\
5 & $142.9 \pm 4.6$ \\
6 & $136.6 \pm 4.3$ \\
\hline
\end{tabular}

diographic grains (Fig. $8, D$ to $F$ ). Two exceptions included the paraventricular nucleus (Fig. 8, $D$ and $E$ ) and mammillary peduncle where moderate levels of receptors were present. A very high concentration of grains was found in the external layer of the median eminence (Fig. 9). No specific binding was observed in the arcuate nucleus.

Overall, the hippocampus contained a low concentration of CRF receptors (Fig. $8, E$ to $G$ ). Within the hippocampus, the highest concentrations of binding sites were present in the subiculum (Fig. $8 G$ ), the molecular layer of the dentate gyrus, and the CA1 region (Fig. $8 F$ ). Lower concentrations of binding sites were found in the remaining areas of this brain region.

In the midbrain a moderate level of CRF receptors was seen in the inferior colliculus (Fig. 8, $H$ and $l$ ). Within the inferior colliculus, the ventrolateral aspects had higher grain densities than did the dorsomedial portion. Fairly dense labeling of CRF receptors was found in the trochlear nuclei and in the interpedunuclar nucleus (Fig. $8 G$ ). Low levels of CRF receptors were present in the periaqueductal gray, dorsal raphe nucleus (Fig. 8G), and superior colliculus, and very low concentrations were seen in the substantia nigra.

In the pons, the cranial nerve nuclei including the facial (Fig. $8, J$ and $K$ ), trigeminal (Fig. 8, $/$ to $K$ ), cochlear (Fig. 8K), and vestibular nuclei (Fig. $8 K$ ) had very high concentrations of autoradiographic grains. In fact, the highest concentration of CRF-binding sites in the rat CNS was found in the facial nucleus. The medial portions of the vestibular nucleus had a much higher concentration of CRF-binding sites, whereas the lateral and superior aspects of this nucleus had moderate to low concentrations of autoradiographic grains. High grain densities were found in the lateral cervical nucleus (Fig. 8K) and at the point of entry of the eighth nerve. All portions of the nucleus of the spinal tract of the trigeminal nerve (Fig. $8, I$ to $K$ ) had comparable high levels of CRF receptors. Moderate numbers of grains were associated with the hypoglossal (Fig. $8 \mathrm{~L}$ ), lateral reticular, paragigantocellular reticular, parabrachial and dorsal (Fig. $8 \mathrm{~J}$ ), and ventral tegmental nuclei. The pontine nuclei (Fig. 8, G and $H$ ) themselves and the raphe pontis nucleus (Fig. 8, $/$ and $J$ ) contained moderate to low numbers of grains, whereas the pontine reticular nuclei (Fig. $8 \mathrm{H}$ ) had a very low density of CRF receptors. Very low levels of receptors were found in the locus ceruleus (Fig. $8 J$ ).

In the medulla, the highest receptor densities were found in the cuneate and gracilis nuclei (Fig. $8 \mathrm{~L}$ ). High grain densities were also found in the inferior olive (Fig. 8L). The concentration of CRF receptors was variable (average of low to moderate) in the nucleus of the solitary tract, the solitary tract (Fig. $8 \mathrm{~L}$ ), and throughout the extent of the pyramids (Fig. 8, $K$ and $L$ ).

In the cerebellum, CRF receptors were present in all parts of the cerebellar cortcx, with highest concentrations in the granular layer (Fig. 8, $J$ and $K$ ). The medial nucleus and the interpositus nucleus (Fig. $8 K$ ) had high receptor levels.

In the cervical spinal cord, moderate levels of receptors were seen in the gray matter with lower levels found in the dorsal horn layers 1 to 4 (Fig. 10).

\section{Discussion}

Biochemical receptor binding studies in slide-mounted forebrain sections using conditions identical to those used in autoradiographic experiments have identified high affinity and pharmacologically specific binding sites for $\mathrm{Nl}^{21},{ }^{125} \mid \mathrm{Tyr}^{32}$-oCRF in rat brain. The kinetic characteristics and peptide specificity of the $\mathrm{Nle}^{21},{ }^{125} \mathrm{I}-\mathrm{Ty}^{32}$-oCRFbinding site in rat brain were comparable to those for the CRF receptor in the anterior lobe of rat (Wynn et al., 1983; De Souza et al., 1984a; Holmos ct al., 1984), human (De Souza et al., 1985), and bovine (De Souza and Kuhar, 1985) pituitary glands and in the rat intermediate pituitary gland (De Souza et al., 1984a). These data substantiate earlier suggestions (Peterfreund and Vale, 1983; Valentino et al., 1983; D. R. Britton et al., 1984) that some structural requirements for CRF activity are shared by brain and pituitary receptors.

The densities of CRF receptors in the rat CNS are generally consistent with the relative distribution of CRF-immunoreactive (CRFIR) terminals (Bloom et al., 1982; Bugnon et al., 1982; Olschowka et al., 1982; Cummings et al., 1983; Joseph and Knigge, 1983; Lerenth et al., 1983; Merchenthaler et al., 1983; Paull and Gibbs, 1983; Swanson et al., 1983). For example, CRF receptors are present in most of the hypothalamus with the highest concentrations of binding sites present in the external layer of the median eminence, where the most intense concentration of CRF fibers is also found. Also, CRF cell bodies in the neocortex are concentrated in laminae 2 and 3 , with projections to laminae 1 and 4 , areas rich in CRF receptors. Additional areas of good correspondence between the distribution of CRF-IR nerve terminals and $\mathrm{Nl}^{21}{ }^{125} / \mathrm{Ty}^{32}$-oCRF binding sites include the olfactory tubercle, caudate-putamen, nucleus of the diagonal band of Broca, medial and lateral septal nuclei, the cranial nerve nuclei in the brainstem-in particular, the facial, principal oculomotor, trochlear, trigeminal, and hypoglossal nuclei, and in other brainstem regions including the central gray, inferior olive, reticular formation, and cuneate and parabrachial nuclei.

There are areas in the rat CNS in which the distributions of CRFIR nerve fibers and CRF receptors do not correlate as well. Some of these areas include the olfactory bulb, amygdala, cerebellum, and spinal cord. In the amygdala, CRF cell bodies and nerve terminals appear confined primarily to the central nucleus (Olschowka et al., 
TABLE III

Distribution of CRF-binding sites in the rat CNS

The data are based on observations from two (no SEM) or three animals The anatomical terminology is derived from Paxinos and Watson (1982). CRF-binding sites were visualized using $0.7 \mathrm{nM} \mathrm{Nle}^{21},{ }^{125} / \mathrm{Tyr}^{32}-\mathrm{OCRF}$. At this concentration of ligand, approximately $10 \%$ of the total number of binding sites are occupied. Autoradiograms of rat brain, rat spinal cord, and iodinated gray (bovine caudate) and white (bovine corpus callosum) sections (all 8 $\mu \mathrm{m})$ were generated with tritium-sensitive Ultrofilm $(\mathrm{LKB})$. An analysis of $\mathrm{Nl}^{21}$, ${ }^{125}$ - $\mathrm{Tyr}^{32}$-oCRF binding in the different regions of rat CNS was performed by computerized image analysis densitometry, and the film optical density was related to the molar concentration of radioactivity by use of the standard curve generated and analyzed concomitantly with the autoradiograms.

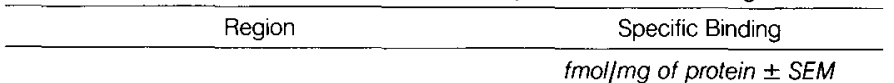

Frontoparietal Cortex (somatosensory)

Laminae I and II

Laminae III and IV

Laminae $V$ and $V I$

$68.7 \pm 6.2$

$98.6 \pm 6.4$

$71.2 \pm 5.5$

Frontoparietal Cortex (motor)

Laminae I and II

Laminae III and $\mathrm{N}$

$48.3 \pm 3.9$

Laminae $V$ and $V$

$74.3 \pm 3.9$

$58.0 \pm 4.1$

Striate Cortex (area 18a)

Laminae I and II

$35.3 \pm 7.4$

Laminae III and IV

$82.6 \pm 6.5$

Laminae $V$ and $V$

$53.9 \pm 5.5$

Cingulate Cortex (all laminae)

Entorhinal Cortex (all laminae)

Olfactory Tubercle

Basal Ganglia

Caudate-putamen

$43.6 \pm 4.1$

$76.1 \pm 9.3$

$65.6 \pm 11.6$

$47.2 \pm 3.7$

Globus pallidus

Claustrum

$16.5 \pm 0.5$

$78.8 \pm 13.3$

Septal Area

Nucleus accumbens

Nucleus of the diagonal band (Broca)

Lateral septal nucleus

Medial septal nucleus

Triangular septal nucleus

Bed nucleus of the stria terminalis

Amygdala

Basolateral nucleus

Central nucleus

Medial nucleus

$\pm 3.8$

$21.6 \pm 2.8$

$25.6 \pm 2.7$

Thalamus

Lateral

Medial

Anterodorsal thalamic nucleus

$37.5 \pm 4.5$

$21.2 \pm 3.7$

29.7

Habenula (medial plus lateral)

$33.5 \pm 3.3$

Hypothalamus

Lateral

Medial

Anterior

Paraventricular nucleus

Arcuate nucleus

Mammillary peduncle

Hippocampus (whole)

Dentate gyrus

Subiculum
TABLE III-continued

\begin{tabular}{cc}
\hline Region & Specific Binding \\
\hline & fmol/mg of protein \pm SEM
\end{tabular}

Midbrain

Inferior colliculus

$43.1 \pm 9.2$

Dorsal raphe nucleus

$8.2 \pm 6.2$

Central gray

$22.4 \pm 1.6$

Medulla-Pons

Inferior olive

$75.8 \pm 8.4$

Superior olive

Lateral reticular nucleus

Paragigantocellular reticular nucleus

Nucleus of the spinal tract of the trigeminal nerve

Cuneate nucleus

Gracile nucleus

Nucleus of the solitary tract

$71.3 \pm 13.4$

$61.8 \pm 9$ ?

49.7

$96.1 \pm 14.1$

$88.1 \pm 6.7$

$86.1 \pm 10.1$

$42.4 \pm 23.1$

$58.6 \pm 10.3$

29.1

Lateral vestibular nucleus

Medial vestibular nucleus

$73.9 \pm 4.7$

Facial nucleus

Lateral cervical nucleus

Vestibulocochlear nucleus

Cochlear nucleus

Dorsal tegmental nucleus

Ventral tegmental nucleus

Parabrachial nucleus

Pontine nucleus

Hypoglossal nucleus

Pyramids

Locus Ceruleus

$150.6 \pm 28.4$

$92.1 \pm 17.4$

$107.4 \pm 24.2$

83.9

$43.5 \pm 13.0$

61.1

59.4

33.2

$65.4 \pm 6.9$

$44.9 \pm 20.6$

$9.1 \pm 7.1$

Cerebellum (all lobules)

Interpositus nucleus

$98.5 \pm 12.7$

71.3

92.2

Paraflocculus

$118.1 \pm 20.0$

Spinal Cord (cervical)

Dorsal horn (Rexed 14 )

$23.5 \pm 09$

44.3

Dorsal horn (Rexed 4-6)

$40.3 \pm 1.4$

White Matter Tracts

Corpus callosum

Forceps minor corpus callosum

$7.5 \pm 4.9$

Fornix

$6.3 \pm 4.7$

0

Anterior commissure

$25.0 \pm 2.7$

Optic chiasm

1982; Cummings et al., 1983; Merchenthaler et al., 1983; Swanson et al., 1983), whereas the highest concentration of CRF receptors is present in the basolateral nucleus. The cerebellum provides a very striking example of a disparity between the anatomical distribution of $\mathrm{Nle}^{21},{ }^{125}-\mathrm{Tyr}^{32}$-oCRF-binding sites and CRF-IR fibers. In the rat cerebellum, moderate (Merchenthaler et al., 1983; Cummings et al., 1983), low (Olschowka et al., 1982), and undetectable (Swanson et al., 1983) densities of CRF-IR fibers have been reported. In contrast, the concentration of cerebellar binding sites is one of the highest in the rat CNS. In the spinal cord, laminae I and $\|$ of the dorsal horn contained the highest numbers of CRF-IR fibers (Olschowka et al., 1982; Schipper et al., 1983), areas of low CRF binding site density.

Similar mismatches between the levels of receptor and neurotransmitter have been noted in previous studies (Palacios and Kuhar, 1980; Palacios et al., 1980; Wamsley et al., 1982; Zarbin et al., 1983; Goedert et al., 1984; Mantyh et al., 1984), and the "mismatch 
problem" has been the topic of a recent report (Kuhar, 1985). There should not be a match between receptor and neurotransmitter at the light microscopic level in whole sections. Neurotransmitter is contained throughout a neuron, whereas the receptor is contained in the postsynaptic neuron which has a different spatial distribution. Perhaps only when both neurons are interneurons and contained within the same region would a match be expected. Technical limitations in both autoradiographic and immunocytochemical experiments may prevent the complele and appropriate identification of receptor and neurotransmitter molecules, respectively. Subtypes of the CRF receptor may exist which only bind under an appropriate set of conditions such as ligand concentration, salts, and guanyl nucleotides. Also, agonist ligands similar to the radioiodinated CRF analogue used in the present study primarily label high affinity states of the receptor which may not be found in constant proportions in all regions of the CNS. Immunohistochemistry, in contrast, is dependent on the specificity of the antisera used. Most of the reports (see above) on the immunohistochemical distribution of CRF in rat brain have utilized primary antibodies directed against ovine CRF. Different distributions of CRF immunoreactivity in the rat CNS were recently reported using a variety of antibodies directed against rat and ovine CRF (Skofitsch and Jacobowitz, 1984). Future studies utilizing more specific antisera in combination with better radioligands may minimize the discrepancics between the distribution of CRF receptors and of CRF immunoreactivity.

Low to moderate concentrations of CRF-binding sites are present in several regions of the rat CNS known to contain primary groups of CRF-IR cell bodies such as the paraventricular nucleus of the hypothalamus, the central nucleus of the amygdala, the bed nucleus of the stria terminalis, and the nucleus of the solitary tract. These CRF-binding sites may represent presynaptic autoreceptors or receptors for internuclear communication which may play important roles in regulating peptide release originating from these perikarya.

CRF-binding sites are present in high concentrations in the median eminence. We are presently investigating the pharmacological characteristics of these CRF-binding sites in the median eminence. Several alternatives exist to explain the nature of the CHF binding in the median eminence. The binding sites may be presynaptic autoreceptors regulating the release of $\mathrm{CRF}$ into the portal vasculature. The CRF-binding sites in the median eminence may also represent interactions of CRF with proteins associated with ependymal tanycytes which may function to transport CRF from the cerebrospinal fluid to the hypophysial portal vasculature (Zimmerman et al., 1973). Another possibility is that the CRF binding in the median eminence may be to CRF receptors on blood vessels similar to those described for vasopressin (Schiffrin and Genest, 1983). Although the precise role of these CRF-binding sites is unclear, similar distributions of receptors in the median eminence have been reported for other hypothalamic hypophysiotropic neurotransmitters such as vasopressin (Brinton et al., 1984) and dopamine (Cronin and Weiner, 1979).

There is relatively good correspondence within the rat CNS between areas containing CRF receptors and anatornic loci which are electrophysiologically responsive to CRF. Iontophoretic application of CRF excited in the cortex and hypothalamus and inhibited in the thalamus and lateral septal area spontaneously occurring action potentials (Eberly et al., 1983). CRF has also been demonstrated to produce excitation of hippocampal pyramidal cells in an in vitro hippocampal slice preparation (Aldenhoff et al., 1983). Direct microapplication of CRF to parabrachial neurons increased the discharge rate of these cells (Valentino et al., 1983). Intracerebroventricular administration of low doses of CRF in rats produced changes in clcctroencephalographic activity suggestive of increased arousal, whereas high doses of CRF elicited seizures that appeared electroencephalographically to originate in the amygdala (Ehlers et al., 1983). In contrast to the good correlation between the presence of CRF receptors and electrophysiologically responsive cells described above, CRF has been shown to dircctly activate noradrenergic neurons of the locus ceruleus (Valentino et al., 1983), an area with a low concentration of CRF-binding sites.
A role has been proposed for CRF in the control of food intake (Morley and Levine, 1982; D. R. Britton et al., 1982, 1984; Gosnell et al., 1983; Levine et al., 1983). The medial and lateral hypothalamus represent important brain areas that are involved in regulating food intake (see Stevenson 1969; Grossman, 1975). The hypothalamus may represent a primary site of action for integrating some endocrine and behavioral effects of CRF. Microinfusion of CRF into the arcuateventromedial area of the hypothalamus suppresses sexual behavior (Sirinathsinghii et al., 1983). In addition, intracerebroventricular injections of CRF have been shown to have antipyretic effects (Bernardini et al., 1984), to inhibit the release of growth hormone (Ono et al., 1984; Rivier and Vale, 1984b), luteinizing hormone (One et al., 1984; Rivier and Vale, 1984a), vasopressin, and oxytocin (Plotsky et al., 1984), and to have delelerious actions on reproductive functions (Rivier and Vale, 1984a). CRF can stimulate the secretion of somatostatin by cultured rat hypothalamic and cerebral cortical cells (Peterfreund and Vale, 1983).

The distribution of CRF receptors in the rat olfactory system is striking. Within the olfactory bulb, the CRF-binding sites are discretely localized in the glomerular layer where the primary olfactory afferent axons terminate (Sheppard, 1979) and in the adjacent external plexiform layer and in the mitral cell body layer where the olfactory output neurons originate (Sheppard, 1979). There is evidence in the literature suggesting that sexual, reproductive, social, and feeding behaviors of most mammalian species are mediated by olfactory substances and pheromonal agents acting through the olfactory system (see Whitten and Bronson, 1970). CRF influences both feeding behavior and sexual activity (see above). Although the hypothalamus is the primary anatomical locus regulating sexual activity and feeding behavior, hypothalamic neuronal activity can be modulated by olfactory impulses relayed through the circuit involving the olfactory bulb, pyriform cortex, amygdala, and subiculum (Lohman, 1963; Powell et al., 1965; Cain and Bindra, 1972; Dreifuss, 1972; Kretteck and Price, 1978a, b); moderate to high densities of CRF receptors are present throughout the circuits.

CRF injected intracerebroventrically produced dose-dependent locomotor activation (Sutton et al., 1982; D. R. Britton et al., 1982 , 1984; Koob et al., 1984). High concentrations of CRF receptors were detected in several brain areas subserving motor function. These structures include the caudate-putamen, the cerebellum, and the facial and hypoglossal motor cranial nerve nuclei. Our localization of CRF-binding sites in the ventral horn of the spinal cord may demonstrate another potential site for CRF to centrally affect motor activity

CRF acts within the CNS to elicit changes in the activity of the autonomic nervous system similar to those changes produced by many forms of stress. The autonomic effects of CRF are evident in a variety of species including rats (Brown et al., 1982a, b, c, 1984; Fisher et al., 1982, 1983; Tache et al., 1983, 1984; Fisher and Brown, 1984; Hamel and Tache, 1984), dogs, (Brown et al., 1982c; Tache et al., 1984), sheep (Scoggins et al., 1984), and monkeys (Kalin et al., 1983; Insel et al., 1984), and include increased plasma concentrations of epinephrine, norepinephrine, glucose, glucagon, cardiovascular parameters such as heart rate and mean arterial pressure, and decreased gastric acid secretion. The present study provides an anatomical basis for some of the observed effects of CRF on autonomic function. CRF may produce some of its eflects via receptors in the parabrachial nucleus, medullary reticular formation, nucleus of the solitary tract, or other brainstem areas known to participate in autonomic regulation. CRF-binding sites are also present in several forebrain regions that exert a powerful influence on autonomic outflow. These regions include the hypothalamus, especially the paraventricular nucleus, bed nucleus of the stria terminalis, amygdala, septum and hippocampus, and cingulate cortex. The autonomic effects of CRF administration may also be mediated by receptors in the spinal cord as suggested by effects of intrathecal injections of CRF at the lumbar level to inhibit gastric acid secretion (Hamel and Tache, 1984).

The immunohistochemical, electrophysiological, behavioral, phar- 
macological, and receptor studies provide compelling evidence that endogenous CRF may function as a neurotransmitter in the CNS. The data discussed above suggest a key role for this neuropeptide in the endocrine, autonomic, and behavioral responses 10 stress that are characteristic of Selye's "general adaptation syndrome." There are some preliminary studies that support a role for endogenous CRF in stress. Footshock stress increased the CSF levels of CRF immunoreactivity in rats (K. T. Britton et al., 1984). Central administration of a CRГ receptor antagonist in rats produced dosedependent inhibition of the plasma epinephrine response to ether stress- or insulin-induced hypoglycemia (Brown et al., 1984).

In summary, we have used the radioiodinated ovine CRF analogue, $\mathrm{Nle}^{21},{ }^{125}$-Tyr ${ }^{32}$-oCRF to map CRF-binding sites in the rat CNS using in vitro labcling autoradiographic techniques. The areas of distribution of CRF-binding sites are correlated well with the immunohistochemical distribution of CRF pathways and pharmacological sites of action of CRF. These data strongly support a physiological role for endogenous CRF in regulating and integrating CNS activity and suggest the importance of this neuropeptide in regulating endocrine and visceral functions and behavior, especially in response to stressful stimuli. The exact mechanisms by which CRF can modulate these complex functions remain unknown. Studies to characterize CRF receptors and CRF-containing pathways in the brain provide a means for better understanding the various functions of this neuropeptide in different areas of the CNS.

\section{References}

Aldenhoff, J. B., D. L. Gruol, J. Rivier, W. Vale, and G. R. Siggins (1983) Corticotropin-releasing factor decreases post-burst hyperpolarizations and excites hippocampal pyramidal neurons in vitro. Science 221: 875-876.

Al-Noaemi, M. C., J. A. Edwardson, and D. Hughes (1982) Corticotropinreleasing factor (CRF) stimulates release of peptides from the intermediate lobc of the rat pituitary gland. J. Physiol. (Lond.) 332: 85-86.

Bernardini, G. L., D. B. Richards, and J. M. Lipton (1984) Antipyretic effect of centrally administered CRF. Peptides 5: 57-59.

Blourn, F. E., E. L. F. Battenberg, J. Rivier, and W. Vale (1982) Corticotropinreleasing factor (CRF): Immunoreactive neurones and fibers in rat hypothalamus. Regul. Pept. 4: 43-48.

Brinton, R. E., K. W. Gee, J. K. Wamsley, T. P. Davis, and H. I. Yamamura (1984) Regional distribution of putative vasopressin receptors in rat brain and pituitary by quantitative autoradiography. Proc. Natl. Acad. Sci. U. S. A. $81: 7248-7252$

Britton, D. R., G. F. Koob, J. Rivier, and W. Vale (1982) Intraventricular corticotropin-releasing factor enhances behavioral effects of novelty. Life Sci. 31: 363-367.

Britton, D. R., D. K. Hoffman, K. Lederis, and J. Rivier (1984) A comparison of the behavioral effects of CRF, sauvagine and urotensin I. Brain Res. 304: 201-205.

Britton, K. T., M. Lyon, W. Vale, and G. F. Koob (1984) Stress-induced secretion of corticotropin-releasing factor immunoreactivity in rat cerebrospinal fluid. Soc. Neurosci. Abstr. 10: 94

Brown, M. R., L. A. Fisher, J. Rivier, J. Spiess, C. Rivier, and W. Vale (1982a) Corticotropin-releasing factor: Effects on the sympathetic nervous system and oxygen consumption. Life Sci. 30: 207-210.

Brown, M. R., L. A. Fisher, J. Spiess, C. Rivier, J. Rivier, and W. Vale (1982b) Corticotropin-releasing factor: Actions on the sympathetic nervous system and metabolism. Endocrinology 111: 928-931.

Brown, M. R., L. A. Fisher, J. Spiess, I. Rivier, C. Rivier, and W. Vale (1982c) Comparison of the biologic actions of corticotropin-releasing factor and sauvagine. Regul. Pept. 4: 107-114.

Brown, M. R., L. A. Fisher, W. W. Vale, and J. E. Rivicr (1984) Corticotropinreleasing factor: Role in central nervous system regulation of the adrenal medulla. Soc. Neurosci. Abstr. 10: 1117.

Bugnon, C., D. Fellmann, A. Gouget, and J. Cardol (1982) Corticoliberin in rat brain: Immunocytochemical identification and localization of a novel neuroglandular system. Neurosci. Lett. 30: 25-30.

Cain, D. P., and D. Bindra (1972) hesponses of amygdala single units to odors in the rat. Exp. Neurol.35: 98-110.

Cote, J., G. LeFevre, F. Labrie, and N. Barden (1983) Distribution of corticotropin-releasing factor in ovine brain determined by radioimmunoassay. Regul. Pept. 5: 189-195.
Cronin, M. J., and R. I. Weiner (1979) ${ }^{3} \mathrm{H}$-Spiroperidol (spiperone) binding to a putative dopamine receptor in sheep and steer pituitary and stalk median eminence. Endocrinology 104: 307-312.

Cummings, S., R. Elde, J. Ells, and A. Lindall (1983) Corticotropin-releasing factor immunoreactivity is widely distributed within the central nervous system of the rat: An immunohistochemical study. J. Neurosci. 3: 13551368.

De Souza, E. B., and M. J. Kuhar (1985) Corticotropin-releasing factor receptors: Recent studies. Res. Publ. Assoc. Res. Nerv. Ment. Dis. 63: in press

De Souza, E. B., M. H. Perrin, J. E. Rivier, W. W. Vale, and M. J. Kuhar (1984a) Corticotropin-releasing factor receptors in rat pituitary gland: Autoradiographic localization. Brain Res. 296: 202-207.

De Souza, E. B., M. H. Perrin, T. R. Insel, J. Rivier, W. W. Vale, and M. J. Kuhar (1984b) Corticotropin-releasing factor receptors in rat forebrain: Autoradiographic identification. Science 224: 1449-1451.

De Souza, E. B., M. H. Perrin, P. J. Whitehouse, J. E. Rivier, W. W. Vale, and M. J. Kuhar (1985) Corticotropin-releasing factor receptors in human pituitary gland: Autoradiographic localization. Neuroendocrinology 40 419-422.

Dreifuss, J. J. (1972) Effccts of electrical stimulation of the amygdaloid complex on the ventromedial hypothalamus. In The Neurobiology of the Amygdala, B. E. Eleftheriou, ed., pp. 295-317, Plenum Press, New York.

Eberly, L. B., C. A. Dudley, and R. L. Moss (1983) lontophoretic mapping of corticotropin-releasing factor (CRF) sensitive neurones in the rat forebrain Peptides 4: 837-841.

Ehlers, C. L., S. J. Henriksen, M. Wang, J. Rivier, W. W. Vale, and F. E. Bloom (1983) Corticotropin-releasing factor produces increases in brain excitability and convulsive seizures in rats. Brain Res. 278: 332-336.

Fischman, A. J., and R. L. Moldow (1982) Extrahypothalamic distribution of CRF-like immunoreactivity in the rat brain. Peptides 1: 149-153.

Fisher, L. A., and M. R. Brown (1984) Corticotropin-releasing factor and angiotensin. II. Comparison of CNS actions to influence neuroendocrine and cardiovascular function. Brain Res. 296: 41-47.

Fisher, L. A., J. Rivier, C. Rivier, J. Spiess, W. W. Valc, and M. R. Brown (1982) Corticotropin-releasing factor (CRF): Central effects on mean arterial pressure and heart rate in rats. Endocrinology 110: 2222-2224.

Fisher, L. A., G. Jessen, and M. R. Brown (1983) Corticotropin-releasing factor (CRF): Mechanism to elevate mean arterial pressure and heart rate. Regul. Pept. 5: 153-161.

Gibbs, D. M., K. U. Stewart, W. Vale, J. Rivier, and S. S. C. Yen (1982) Synthetic corticotropin-releasing factor stimulates secretion of immunoreactive beta-endorphin/beta-lipotropin and $\mathrm{ACTH}$ by human fetal pituitaries in vitro. Life Sci. 32: 547-550.

Goedert, M., P. W. Mantyh, P. C. Emson, and S. Hunt (1984) Inverse relationship between neurotensin receptors and neurotensin-like immunoreactivity in the cat striatum. Nature 307: 543-546.

Gold, P. W., G. Chrousos, C. Kellner, R. Post, A. Roy, P. Augerinos, H Schulte, E. Oldfield, and D. L. Loriaux (1984) Psychiatric implications of basic and clinical studies with corticotropin-releasing factor. Am. J. Psychiatry 141: 619-627

Gosnell, B. A., J. E. Morley, and A. S. Levine (1983) Adrenal modulation of the inhibitory effect of corticotropin-releasing factor on feeding. Peptides 4: $807-812$

Grossman, A., A. C. N. Kruseman, L. Perry, S. I omlin, A. V. Schally, D. H Coy, L. H. Rees, A. M. Comaru-Schally, and G. M. Besser (1982) New hypothalamic hormone, corticotropin-releasing factor, specifically stimulates the release of adrenocorticotropic hormone and cortisol in man. Lancet 1: $921-922$.

Grossman, S. P. (1975) Role of the hypothalamus in the regulation of food and water intake. Psychol. Rev. 82: 200-224.

Hamel, D., and Y. Tache (1984) Intrathecal (I.T.) injection of bombesin and rat CRF inhibits gastric acid secretion in rats. Soc. Neurosci. Abstr. 10 . 812

Harris, G. W. (1948) Neural control of the pituitary gland. Physiol. Rev. 23. 139-179.

Hashimoto, K., K. Murakami, N. Ohno, J. Kageyama, Y. Aoki, J. Takahara and Z. Ota (1983) A specific radioimmunoassay for corticotropin-releasing factor (CRF) using synthetic ovine CRF. Life Sci. 32: 1001-1007.

Holmes, M. C., F. A. Antoni, and T. Szeintendnei (1984) Pituitary receptors for corticotropin-releasing factor: No effect of vasopressin on binding or activation of adenylate cyclase. Neuroendocrinology 39: 162-169.

Hook, V. Y. H., S. Heisler, S. L. Sabol, and J. Axelrod (1982) Corticotropinreleasing factor stimulates adrenocorticotropin and beta-endorphin release from AtT-20 mouse pituitary tumor cells. Biochem. Biophys. Res. Commun. 106: $1364-1371$. 
Insel, T. R., J. A. Aloi, D. Goldstein, J. H. Wood, and D. C. Jimerson (1984) Plasma cortisol and catecholamine responses to intracerebroventricular administration of CRF to rhesus monkeys. Life Sci. 34: 1873-1879.

Joseph, S. A., and K. M. Knigge (1983) Corticotropin-releasing factor: Immunocytochemical localization in rat brain. Neurosci. Lett. 35: 135-141.

Kalin, N. H., S. E. Shelton, G. W. Kraemer, and W. T. McKinney (1983) Corticotropin-releasing factor administered intraventricularly to rhesus monkeys. Peptides 4: 217-220.

Koob, G. F., N. Swerdlow, M. Seeligson, R. Sutton, J. Rivier, and W. Vale (1984) Effects of alpha flupcnthixol and naloxone on CRF-induced locomotor activation. Neuroendocrinology 39: 459-464.

Kretteck, J. E., and J. L. Price (1978a) A description of the amygdaloid complex in the rat and cal with observations on intra-amygdaloid axonal projections. J. Comp. Neurol. 178: 255-280.

Kretteck, J. E., and J. L. Price (1978b) Amygdaloid projection to subcortical structures within the basal torebrain and brainstem in the rat and cat. $\mathrm{J}$. Comp. Neurol. 178: 225-254.

Kuhar, M. J. (1985) The mismatch problem in receptor mapping studies. Trends Neurosci. 8: 190-191.

Kuhar, M. J., and J. R. Unnerstall (1985) Receptor mapping by autoradiography: Some current technical problems. Trends Neurosci. 8: 49-53.

Lerenth, C., F. A. Antoni, and M. Palkovits (1983) Ultrastructural demonstration of ovine CRF-like immunoreactivity (oCRF-LI) in the rat hypothalamus: Processes of magnocellular neurons establish membrane specializations with parvocellular neurons containing oCRF-LI. Regul. Pept. 6: 179-188.

Levine, A. S., B. Rogers, J. Kneip, M. Grace, and J. E. Morley (1983) Effect of centrally administered corticotropin-releasing factor (CRF) on multiple feeding paradigms. Neuropharmacology 22: 337-339.

Lohman, A. H. M. (1963) The anterior olfactory lobe of the guinea pig. A descriptive and experimental anatomical study. Acta Anat. (Basel) 53 (Suppl. 49): 1-109.

Mantyh, P. W., S. P. Hunt, and J. E. Maggio (1984) Substance P receptors: Localization by light microscopic autoradiography in rat brain using $\left[{ }^{3} \mathrm{H}\right] \mathrm{SP}$ as the radioligand. Brain Res. 307: 147-165.

Merchenthaler, I. S. Vigh, P. Petrusz, and A. V. Schally (1983) The paraventriculo-infundiblar corticotropin-releasing factor (CRF) pathway as revealed by immunocytochemistry in long-term hypophysectomized or adrenalectomized rats. Regul. Pept. 5: 295-305.

Meunier, H., G. Lefevre, D. Dumont, and F. Labrie (1982) CRF stimulates alpha-MSH secretion and cyclic AMP accumulation in rat pars intermedia cells. Life Sci. 31: 2129-2135.

Morley, J. E., and A. S. Levine (1982) Corticotropin-releasing factor, grooming and ingestive behavior. Life Sci. 31: 1459-1464.

Nussbaum, S. R., D. B. Carr, R. M. Bergland, B. Kliman, J. Fisher, B. Reiner, S. Kleshinski, and M. Rosenblatt (1983) Dynamics of cortisol and endorphin responses to graded doses of synthetic ovine CRF in sheep. Endocrinology 112: 877-879.

Olschowka, J. A., T. L. O'Donohue, G. P. Mueller, and D. M. Jacobowitz (1982) The distribution of corticotropin-releasing factor-like immunoreactive neurons in rat brain. Peptides 3: 995-1015.

Ono, N., M. D. Lumpkin, W. K. Samson, J. K. McDonald, and S. M. McCann (1984) Intrahypothalamic action of corticotropin-releasing factor (CRF) to inhibit growth hormone and $\mathrm{LH}$ release in the rat. Life Sci. 35: 1117-1123.

Orth, D. N., R. V. Jackson, G. S. DeCherney, C. R. DeBold, A. N. Alexander, D. P. Island, C. Rivier, J. Spiess, and W. W. Vale (1983) Effect of synthetic ovine corticotropin-releasing factor: Dose response of plasma adrenocorticotropin and cortisol. J. Clin. Invest. 71: 587-595.

Palacios, J. M., and M. J. Kuhar (1980) Beta-adrenergic receptor localization by light microscopic autoradiography. Science 208: 1378-1380.

Palacios, J. M., W. S. Young, III, and M. J. Kuhar (1980) Autoradiographic localization of gamma-aminobutyric acid (GABA) receptors in rat cerebellum. Proc. Natl. Acad. Sci. U. S. A. 77: 670-674.

Palacios, J. M., D. L. Niehoff, and M. J. Kuhar (1981) Receptor autoradiog. raphy with tritium-sensitive film: Potential for computerized densitometry. Neurosci. Lett. 25: 101-105.

Palkovits, M., M. J. Brownstein, and W. W. Vale (1983) Corticotropin-releasing factor (CRF) immunoreactivity in hypothalamic and extrahypothalamic nuclei of sheep brain. Neuroendocrinology 37: 302-305.

Paull, W. K., and F. P. Gibbs (1983) The corticotropin-releasing factor (CRF) neurosecretory system in intact, adrenalectomized, and adrenalectomizeddexamethasone treated rats. Histochemistry 78: 303-316.

Paxinos, G., and C. Watson (1982) The Rat Brain in Stereolaxic Coordinates, Academic Press, Inc., New York.

Peterfreund, R. A., and W. W. Vale (1983) Ovine corticotropin-releasing factor stimulates somatostatin secretion from cultured brain cells. Endocrinology 112: $1275-1278$.
Plotsky, P. M., T. O. Bruhn, and S. Otto (1984) Corticotropin-releasing factor (CRF) inhibits secretion of arginine vasopressin and oxytocin into rat hypophysial portal plasma. VIIth International Congress on Endocrinology Abstracts, p. 2052

Powell, T. P. S., W. M. Cowan, and G. R. Raisman (1965) The central olfactory connections. J. Anat. 99: 791-813.

Proulx-Ferland, L., F. Labrie, D. Dumont, J. Cote, D. H. Coy, and J. Sveiraf (1982) Corticotropin-releasing factor stimulates secretion of melanocytestimulating hormone from the rat pituitary. Science 217: 62-63.

Rivier, C., and W. Vale (1984a) Influence of corticotropin-releasing factor on reproductive functions in the rat. Endocrinology 114: 914-921.

Rivier, C., M. Brownstein, J. Spiess, J. Rivier, and W. W. Vale (1982) In vivo corticotropin-releasing factor-induced secretion of adrenocorticotropin, beta-endorphin, and corticosterone. Endocrinology 110: 272-278.

Rivier, C., J. Rivier, K. Lederis, and W. W. Vale (1983) In vitro and in vivo ACTH-releasing activity of ovine CRF, sauvagine and urotensin I. Regul. Pept. 5: 139-143.

Rivier, C. R., and W. Vale (1984b) Corticotropin-releasing factor (CRF) acts centrally to inhibit growth hormone secretion in the rat. Endocrinology 114: 2409-2411.

Rivier, J., J Spiess, C. Rivier, R. Galyean, and W. W. Vale (1982) Solid phase synthesis of amunine (CRF), sauvagine and two urotensin I. In Peptides, K. Blaha and P. Malon, eds., pp. 597-602, Wide Gruyter, Berlin.

Sahgal, A., C. Wright, J. A. Edwardson, and A. B. Kcith (1983) Corticotropin releasing factor is more potent than some corticotropin-related peptides in affecting passive avoidance behavior in rats. Neurosci. Lett. 36: 81-86.

Schiffrin, E. L., and J. Genest (1983) ${ }^{3} \mathrm{H}$-Vasopressin binding to the rat mesenteric artery. Endocrinology 113: 409-411.

Schipper, J., H. W. M. Steinbusch, I. Vermes, and F. J. H. Tilders (1983) Mapping of CRF-immunoreactive nerve fibers in the medulla oblongata and spinal cord of the rat. Brain Res. 267: 145-150.

Scoggins, B. A., J. P. Coghlan, D. A. Denton, D. W. Fei, M. A. Nelson, G. W. Treager, J. Tresham and X. -M. Wang (1984) Intracerebroventricular infusions of corticotrophin-releasing factor (CRF) and $\mathrm{ACTH}$ raise blood pressure in sheep. Clin. Exp. Pharmacol. Physiol. 11: 365-368.

Shepherd, G. M. (1979) Synaptic Organization of The Brain, pp. 152-183, Oxford University Press, New York.

Sirinathsinghij, D. J. S., L. H. Rees, J. Rivier, and W. W. Vale (1983) Corticotropin-releasing factor is a potent inhibitor of sexual receptivity in the female rat. Nature 305: 232-235.

Skofitsch, G., and D. M. Jacobowitz (1984) On the specificity of different antibodies directed against ovine and rat CRF in the rat central nervous system. Soc. Neurosci. Abstr. 10: 595.

Spiess, J., J. Rivier, C. Rivier, and W. W. Vale (1981) Primary structure of corticotropin-releasing factor from ovine hypothalamus. Proc. Natl. Acad. Sci. U. S. A. 78: 6517-6521.

Stevenson, J. A. F. (1969) Neural control of food and water intake. in The Hypothalamus, W. Haymaker, E. Anderson, and W. J. H. Nauta, eds., pp. 524-621, Charles C Thomas, Springfield, IL.

Sutton, R. E., G. F. Koob, M. LeMoal, J. Rivier, and W. W. Vale (1982) Corticotropin-releasing factor produces behavioral activation in rats. Nature 297: $331-333$.

Swanson, L. W. P. E. Sawchenko, J. Rivier, and W. W. Vale (1983) Organization of ovine corticotropin-releasing factor immunoreactive cells and fibers in the rat brain: An immunohistochemical study. Neuroendocrinology 36: 165-186

Tache, Y., Y. Goto, M. W. Gunion, W. W. Vale, J. Rivier, and M. Brown (1983) Inhibition of gastric acid secretion in rats by intracerebral injection of corticotropin-releasing factor. Science 222: 935-937.

Tache, Y., Y. Goto, M. Gunion, J. Rivier, and H. Debas (1984) Inhibition of gastric acid secretion in rats and in dogs by corticotropin-releasing factor. Gastroenterology 86: 281-286.

Turkelson, C. M., A. Arimura, M. D. Culler, J. B. Fishback, K. Groot, M. Konda, M. Luciano, C. R. Thomas, J. K. Chang, and M. Shimizu (1981) /n vivo and in vitro release of ACTH by synthetic CRF. Peptides 2: 425-429.

Vale, W., J. Spiess, C. Rivier, and J. Rivier (1981) Characterization of a 41residue ovine hypothalamic peptide that stimulates secretion of corticotropin and beta-endorphin. Science 213: 1394-1397.

Valc, W., J. Vaughn, M. Smith, G. Yamamoto, J. Rivier, and C. Rivier (1983) Effects of synthetic ovine corticotropin-releasing factor, glucocorticoids, catecholamines, neurohypophysial peptides, and other substances on cultured corticulropic cells. Enduciriology 113: 1121-1131.

Valentino, R. J., S. L. Foote, and G. Aston-Jones (1983) Corticotropinreleasing factor activates noradrenergic neurons of the locus ceruleus. Brain Res. 270: 363-367.

Veldhuis, H. D., and D. DeWied (1984) Differential behavioral actions of 
corticotropin-releasing factor (CRF). Pharmacol. Biochem. Behav. 21: $707-$ 713.

Wamsley, J. K., M. A. Zarbin, W. S. Young III, and M. J. Kuhar (1982) Distribution of opiate receptors in the monkey brain: An autoradiographic study. Neuroscience 7: 595-613.

Whitten, W. K., and H. Bronson (1970) The role of pheromones in mammalian reproduction. In Communication by Chemical Signals, J. W. Johnston, Jr., D. G. Moulton, and A. Turk, eds., Vol. 1, pp. 309-326, AppletonCentury-Crofts, New York.

Wynn, P. C., G. Aguilera, J. Morell, and K. J. Catt (1983) Properties and regulation of high-affinity pituitary receptors for corticotropin-releasing factor. Biochem. Biophys. Res. Commun. 110: 602-608.
Yasuda, N., M. A. Greer, and T. Aizawa (1982) Corticotropin-releasing factor. Endocr. Rev. 3: 123-140.

Young, W. S., III, and M. J. Kuhar (1979) A new method for receptor autoradiography: $\left[{ }^{3} \mathrm{H}\right]$-Opioid receptors in rat brain. Brain Res. 179: $255-$ 270.

Zarbin, M. A., R. B. Innis, J. K. Wamsley, S. H. Snyder, and M. J. Kuhar (1983) Autoradiographic localization of cholecystokinin recoptors in rodent brain. J. Neurosci. 3: 877-906.

Zimmerman, E. A., P. W. Carmel, M. K. Husain, M. Ferin, M. Tannebaum, A. G. FranlL, and A. G. Rubirisun (1973) Vasopressin and neurophysin: High concentrations in monkey hypophyseal portal blood. Science 182: 925927. 